\title{
A Review Study on the Main Sources of Porosity in Al-Si Cast Alloys
}

\author{
Agnes Samuel $\left(\mathbb{D},{ }^{1}\right.$ Yasser Zedan, ${ }^{2}$ Herbert Doty, ${ }^{3}$ Victor Songmene, ${ }^{2}$ and Fawzy. H. Samuel ${ }^{1}{ }^{1}$ \\ ${ }^{1}$ Université du Québec à Chicoutimi, Chicoutimi, Quebec, Canada \\ ${ }^{2}$ École de Technologie Supérieure, UQ, Montréal, Quebec, Canada \\ ${ }^{3}$ General Motors Corporation, Materials Engineering, MI 48340, USA
}

Correspondence should be addressed to Fawzy. H. Samuel; fhsamuel@uqac.ca

Received 4 May 2021; Accepted 5 June 2021; Published 22 June 2021

Academic Editor: Daniela Pilone

Copyright (C) 2021 Agnes Samuel et al. This is an open access article distributed under the Creative Commons Attribution License, which permits unrestricted use, distribution, and reproduction in any medium, provided the original work is properly cited.

\begin{abstract}
The present study was performed on A356 and B319 alloys in mechanically stirred or degassed condition. Melts were Sr-modified and grain-refined. Hydrogen content was varied from less than $0.1 \mathrm{ml} / 100 \mathrm{~g} \mathrm{Al}$ to $\sim 0.4 \mathrm{ml} / 100 \mathrm{~g} \mathrm{Al}$; Fe was increased to $0.8 \%$ in B319 alloy. Lanthanum and cerium were added as $99.5 \%$ pure metals. Two main techniques were used to investigate porosity formation: fracture surface of tensile or fatigue test bars, or reduced pressure test (RPT) method. Porosity type and shape were examined. The results show that pore size is more influential than small scattered ones from a mechanical point of view. Tensile testing is affected by porosity located at the center of the testing bar, whereas edge porosity is responsible for crack initiation in case of fatigue testing. Intermetallics precipitate in the form of intercepted platelets which restricts the flow of the molten metal, leading to formation of shrinkage cavities. Precipitation of clusters of compounds from the liquid state such as $\mathrm{Al}_{2} \mathrm{Si}_{2} \mathrm{Sr}, \mathrm{Mg}_{2} \mathrm{Sn}$, $\mathrm{Al}_{3} \mathrm{Ti}$, or added $\mathrm{Al}_{2} \mathrm{O}_{3}$ particles would as well act as nucleation sites for porosity formation. Most oxides were observed in the form of long branched strings. In some cases, bifilms were also reported in addition to $\mathrm{SrO}$ and $\mathrm{MgO}$.
\end{abstract}

\section{Introduction}

Macroscopic cavities occurring in a casting are normally a shrinkage type due to poor feeding. Volumetric shrinkage in metals transforming from liquid to solid state may range from 3 to $10 \%$, with $5-8 \%$ being typical of most cast alloys and taking place in different forms. The other major source of porosity is caused by the dissolution of the hydrogen gas in the solidifying solid as a result of the reduction of hydrogen solubility [1-10]. Majority of porosity observed in castings is caused by a combination of gas and shrinkage. These pores take place mainly in the interdendritic regions, since these are the last parts to solidify [11-13]. It is suggested that the pore nucleation and growth can be expressed as [13-15]

$$
P_{\mathrm{g}}+P_{\mathrm{s}} \geq P_{\mathrm{atm}}+P_{\mathrm{H}}+P_{\mathrm{s}-\mathrm{t}},
$$

where $P_{\mathrm{g}}=$ equilibrium pressure of dissolved gases in the melt; $P_{\mathrm{s}}=$ pressure drop due to shrinkage; $P_{\mathrm{atm}}=$ pressure of the atmosphere over the system; $P_{\mathrm{H}}=$ pressure due to the metallostatic head; and $P_{s-\mathrm{t}}=$ pressure due to surface tension at the pore/liquid interface.
In order for a pore to grow, its internal pressure $\left(P_{\mathrm{i}}=P_{\mathrm{g}}+P_{\mathrm{s}}\right)>\left(P_{\mathrm{ext}}=P_{\mathrm{atm}}+P_{\mathrm{H}}+P_{\mathrm{s}-\mathrm{t}}\right)$ to avoid pore collapse. The dissolved gas pressures $P_{\mathrm{g}}$ and the pressure drop due to shrinkage $P_{s}$ are the main parameters controlling the formation of porosity. Iron and rare earth metal-based intermetallics are considered as favorable sites for porosity formation mainly due to intersection of the intermetallic platelets preventing/retarding the motion of the liquid metal during solidification [16-18].

A new model to predict location-specific volumes of entrained defects as well as oxide induced defects in aluminum castings was developed by Ridgeway et al. [19]. The authors claim that their model (Oxide Entrainment Number) can accurately determine the gaseous pore number in a selected position in the casting. Effect of defect size on tensile elongation in aluminum castings was investigated by Koprowski et al. [20]. The study showed that there is a good correlation to total defect size and the reduction of \% elongation of the samples. Prediction of quantifiable damage that oxide films may cause to the quality of aluminum castings during the filling process remains theoretical, due to 
lack of supporting data. Hoefert [21] carried out a set of experiments to turn on and turn off turbulent filling conditions with film entrapment in order to obtain the needed data required to predict the actual porosity and tensile damage.

The present study was undertaken to highlight some important metallographic aspects of porosity in $\mathrm{Al}-\% \mathrm{Si}$ castings that were observed by our research group during the past two decades in the course of our studies and laboratory experiments, to be shared with other scholars. These castings were produced using different methods, namely, metallic mold, sand mold as well as the application of the RPT and ultrasonic techniques.

\section{Experimental Procedure}

The chemical composition of the base alloy is shown in Table 1 . The ingots were melted in a $40 \mathrm{~kg}$ capacity $\mathrm{SiC}$ crucible using an electrical resistance furnace. The melting temperature was kept at about $750^{\circ} \mathrm{C}$. Addition of alloying elements was made using master alloys depending on the required composition: $\mathrm{Al}-25 \% \mathrm{Fe}, \mathrm{Al}-10 \% \mathrm{Sr}, \mathrm{Al}-5 \% \mathrm{Ti}-1 \% \mathrm{~B}$, Al-10\% Ti, Al-10\% Ti, Al-15\%Zr, pure La, and pure Ce.

The molten metal was either mechanically stirred or subjected to degassing for a sufficient period of time (about 25 minutes) applying high purity, dry argon gas that was introduced into the molten bath at a constant rate of $20 \mathrm{~m}^{3}$ / $\mathrm{h}$, using an impeller made of chemically treated graphite (rotating at $\sim 135 \mathrm{rpm}$ ), to reduce the hydrogen concentration in the molten alloys as well as to ensure the uniform mixing of the additions. Strontium was added towards the end of degassing, followed by another 3 minutes of degassing to ensure complete dissolution of the strontium.

Hydrogen content was varied using different amounts of small potato pieces that were introduced into the molten bath using a perforated graphite plunger. In each case, the hydrogen content was analyzed by casting a sample of the melt in a Ransley mold. This is a mold specially designed to prepare samples for hydrogen analysis using the Leco subfusion technique [22]. Four samples were used for each melt prepared and the average of the four was taken as the hydrogen content of the specific melt. Complete details are provided in [1]. The hydrogen was also monitored using an AlScan apparatus [23].

Three samples for chemical analysis were also taken at the time of the casting; this was done at the beginning, in the middle, and at the end of the casting process to ascertain the exact chemical composition of each alloy. Degassed melt was poured into a metallic permanent mold (ASTM B-108, that was preheated at about $460^{\circ} \mathrm{C}$, DAS $\left.\sim 22-25 \mu \mathrm{m}\right)$ to prepare test bars, the dimensions of which are shown in Figure 1. Samples from mechanically stirred melts were examined using the RPT technique. In certain cases, a sand mold preheated at $150^{\circ} \mathrm{C}$ was used (DAS $10-120 \mu \mathrm{m}$ ) (Figures 2 and 3 ). In addition, porosity in fractured fatigue tested bars (DAS $\sim 15-20 \mu \mathrm{m}$, Figure 4 ) was also investigated [24].

For mechanically stirred melts, for each condition, RPT samples were taken. Samples for metallographic
TABLE 1: Chemical composition of the as-received base alloys used in this study.

\begin{tabular}{lcccccccc}
\hline \multicolumn{10}{c}{ Chemical analysis (wt \%) } \\
Alloy & \multicolumn{10}{c}{ Elements } \\
& $\mathrm{Cu}$ & $\mathrm{Si}$ & $\mathrm{Fe}$ & $\mathrm{Mn}$ & $\mathrm{Mg}$ & $\mathrm{Ti}$ & $\mathrm{Zn}$ & $\mathrm{Al}$ \\
\hline A356 & 0.12 & 7.19 & 0.12 & 0.3 & 0.32 & 0.002 & 0.0031 & Balance \\
B319 & 3.59 & 6.2 & 0.32 & 0.25 & 0.28 & $<0.00$ & $<0.1$ & Balance \\
\hline
\end{tabular}

examination were prepared from the casting. The study was carried out using a Clemex image analyzer in conjunction with an Olympus PMG3 optical microscope. Characterization of the phases observed in both alloys was carried out employing a field emission scanning electron microscope (FESEM) equipped with an EDS system.

\section{Results and Discussion}

3.1. Gas and Shrinkage Porosity. The solubility of hydrogen in pure aluminum, and 319 and 356 aluminum alloys, is shown in Figure 5[25], whereas Figure 6illustrates the porosity development during solidification [26]. The results of Boudreault et al. [27] on the formation of gas porosity in 356 and 319 alloys solidified under different rates (using different molds) are controlled by the amount of absorbed hydrogen and solidification time, applying the same techniques described in the experimental section. The results are presented in Figures 7(a)and 7(b). Figure 8demonstrates the presence of a mixture of gas and shrinkage cavities at the edge of a tensile bar of non-modified A356 alloy in the T6 condition (samples were supplied), whereas long shrinkage cavities can be seen at the center of the sample. In both cases, pores are seen as disconnected (i.e., separated by a few dendrites). However, some of these pores may join the neighboring ones under the applied stress (blue arrow in Figure 8(b)). Figure 8 (c)is a high magnification image of the dendrites in the white circle in (b) revealing two rows of dendrites with a narrow crack passing through whereas Figure $8(\mathrm{~d})$ is an optical micrograph exhibiting the possibility of the growing of gas pores through joining each other (arrowed). Considering the topography of the fracture surface, it is difficult to measure the actual pore size that leads to crack initiation or propagation.

Figure 9depicts the shape and number of pores in Srtreated A356 alloy with two levels of hydrogen $(0.25 \mathrm{ml} / 100 \mathrm{~g}$ and $0.4 \mathrm{ml} / 100 \mathrm{~g} \mathrm{Al}$ ). Figure 9 (a) shows several round pores $(\sim 400 \mu \mathrm{m}$ in diameter) distributed throughout the fracture surface of a tensile bar in T6 temper condition $\left(H_{2}=\sim 0.25 \mathrm{ml} / 100 \mathrm{~g} \mathrm{Al}\right)$. These pores were characterized by their large size $(\sim 400 \mu \mathrm{m}$ in diameter) and relatively shallow depth. Porosity in high hydrogen-containing alloy $(0.4 \mathrm{ml} /$ $100 \mathrm{~g} \mathrm{Al}$ ) is shown in Figure 9(b) where pores are much deeper than those displayed in Figure 9(a). As illustrated in Figure 9(b), their growth was limited by the surrounding dimple structure. In some areas, the bottom of the pore could not be reached as demonstrated in Figure 9(c), long white arrow. 


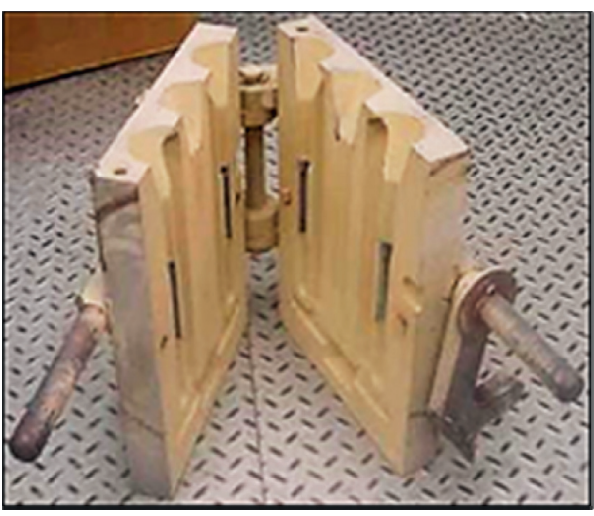

(a)

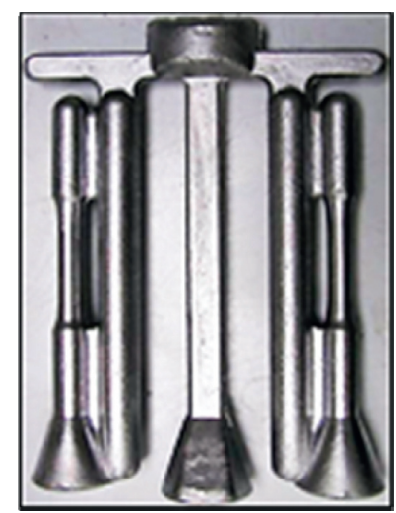

(b)

FIgURE 1: Details of the used permanent metallic mold type ASTM B-108.
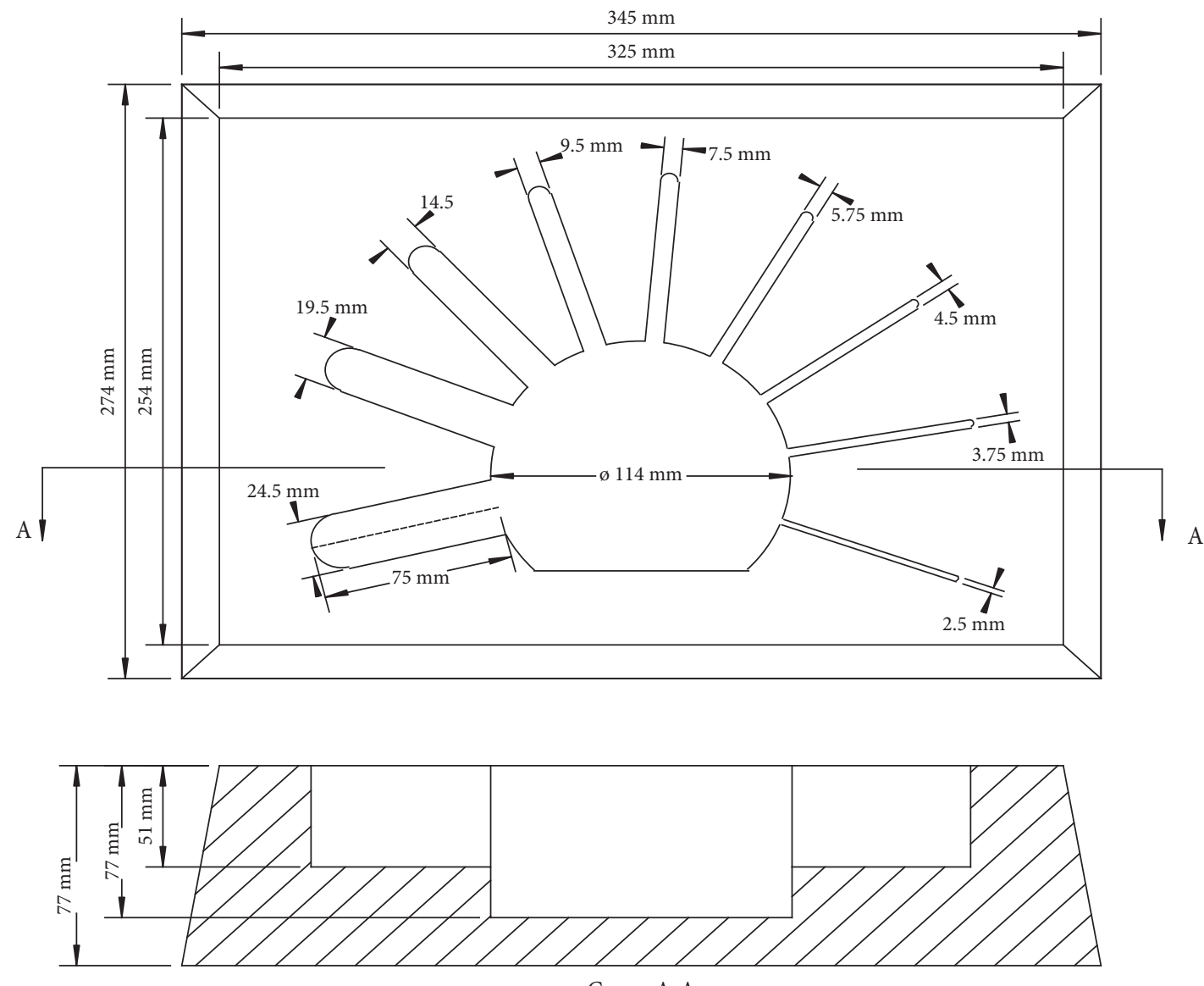

Coupe A-A

Figure 2: Schematic diagram of the sand mold [23].

In all cases, the pore surfaces are covered by fine eutectic $\mathrm{Si}$ particles, arrowed. Some of these particles could be $\mathrm{SrO}$ oxides as shown in Figure 9(d) [26, 27]. Figure 9(e) is a backscattered electron image produced from a similar pore showing the form of the SrO as confirmed from the associated x-ray diagram displayed in Figure 9(f). This part will be discussed in more detail in a separate section. It should be borne in mind that the $\mathrm{Si} \alpha \alpha$ line $(1.739 \mathrm{keV})$ is very close to
$\mathrm{L} \alpha \mathrm{Sr}(1.806 \mathrm{keV})$. Note that in both Figures 8and 9the porosity is caused by excess of $\mathrm{H}_{2}$.

Nevertheless, increasing hydrogen content and hence porosity will lead to reduction in the amount of shrinkage cavities, but not to eliminate them. Figure 10(a)shows a shrinkage cavity where the crack is passing through in $0.4 \mathrm{ml} / 100 \mathrm{~g}$ Al treated A356 alloy (T6 temper) under uniaxial loading. On the other hand, repeated compression/ 


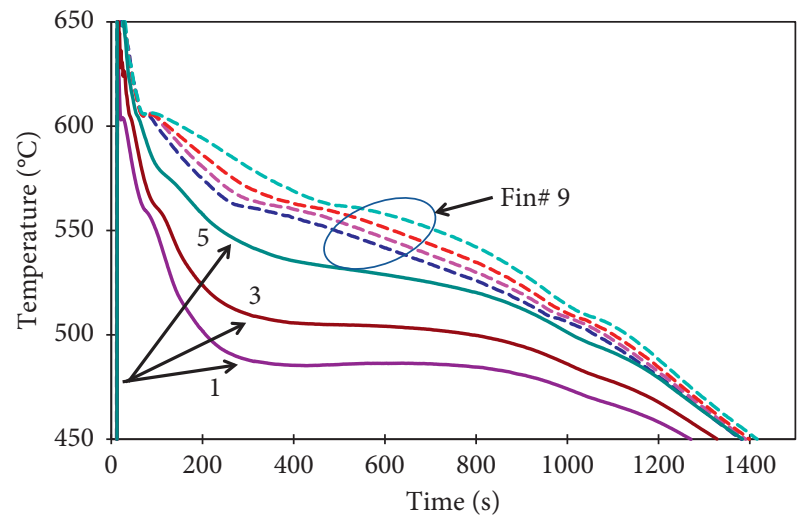

FIgURE 3: Solidification time for each fin.

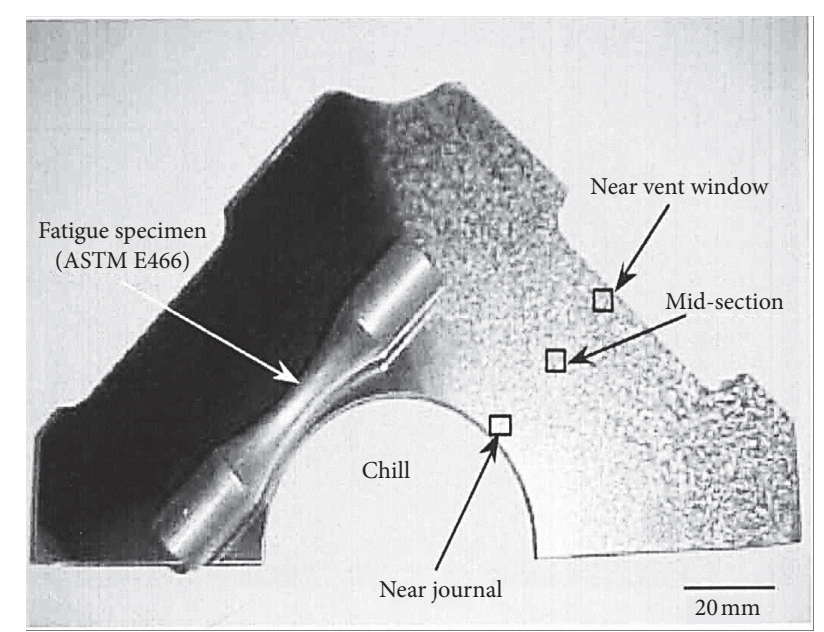

Figure 4: Positions of fatigue samples prepared from a V-shaped engine machine [24].

tension testing may lead to impingement of the dendrites (white circles) narrowing down the spacing between two adjacent sets of dendrites as seen in Figure 10(b). Figure 10(c)represents the microstructure corresponding to a polished sample that was sectioned from a casting poured in a sand mold preheated at $150^{\circ} \mathrm{C}$ showing a severe case of shrinkage formation. The molten material (non-modified A356 alloy) was degassed for about 30 minutes using high purity Ar gas prior to casting (humidity was about 11-13\%).

The results of Magnusson and Arnberg [28] and Leitner et al. [29] show that the density of liquid aluminum-silicon alloy increases with increasing silicon content, while silicon reduces the density in the solid state. Silicon content reduces the solidification shrinkage from 6.6 pct for pure aluminum to 4.4 pct for Al-11.6 pct Si. Deev et al. [30] studied the influence of the melt cooling rate on shrinkage behavior

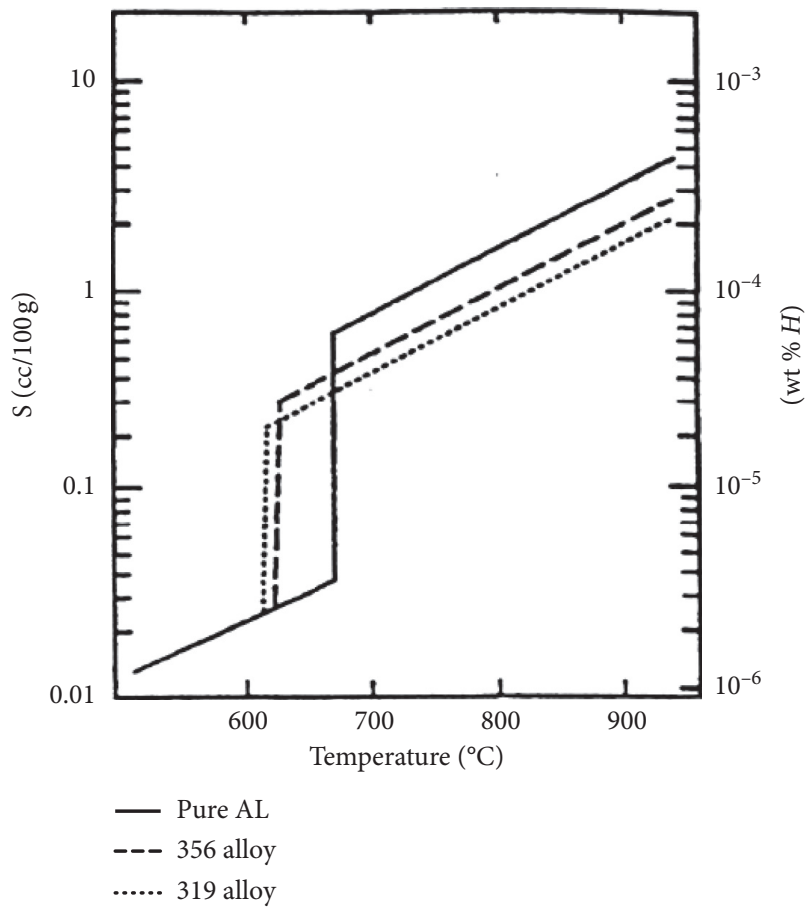

FIGURE 5: Hydrogen solubility of in pure aluminum, and Al-Si cast alloys [25].

during solidification of aluminum alloys. At low cooling rate, the rate of the shrinkage process is much less than the filtration rate and capillary feed, and shrinkage defects are effectively healed. High rates of heat removal from the surface of the casting lead to the frontal nature of crystallization, the mushy zone is practically wedged out, and the rate of healing of hot tears due to filtration again exceeds the rate of their opening due to the shrinkage process.

Ammar et al. [31-33] highlighted the importance of (i) pore position in the casting, size and pore distribution and (iii) inter-pore distance. Figure 11depicts the difference in pore position; pore at the center has less effect on the fatigue life than that on the surface due to stress distribution. In fact, pores at the casting center have a great effect on the premature failure of the castings under uniaxial loading. Examining Figure 12, in the case of separate small pores, the propagation of the crack from one small pore to the next will take a longer time, resulting in increasing the resistance to crack propagation and, hence, longer fatigue life. The high stress concentration associated with a large single pore will enhance the driving force for crack propagation and lead to decreasing the sample fatigue life. Thus, it is the pore size that has a more influential role in determining the fatigue life than disconnected small ones.

The effect of surface porosity on the tensile properties of the used A356 alloy in the T6 condition is illustrated in Figure 13(tensile and fatigue testing at room temperature). As can be seen, regardless of the type of testing, the increase in 


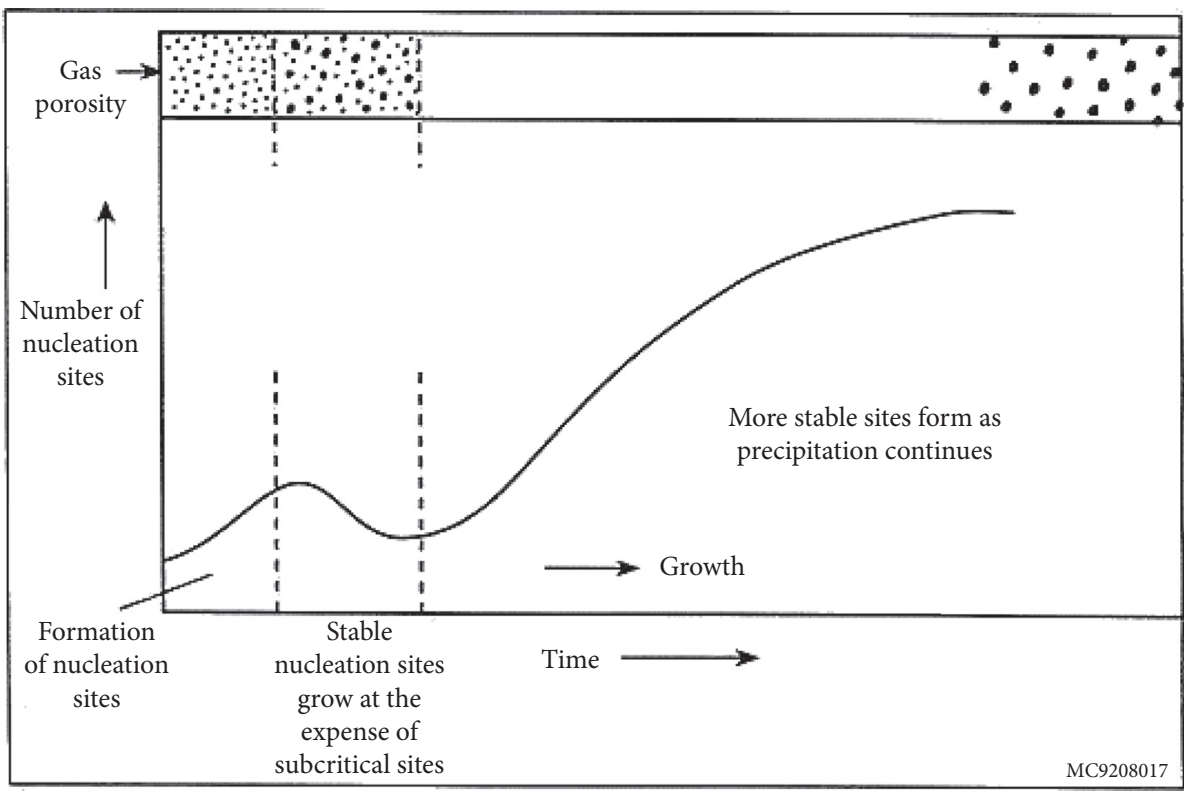

FIgURE 6: Representation of porosity development during solidification [26].

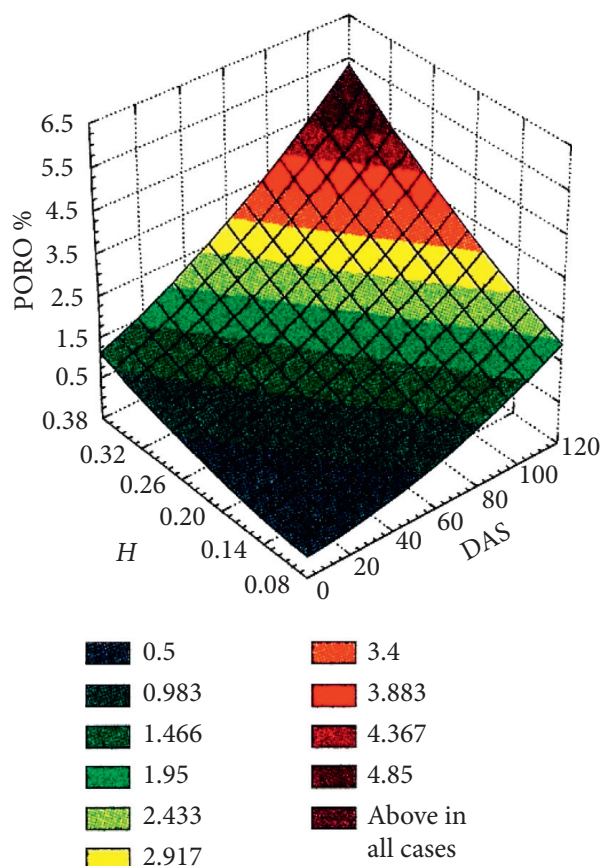

(a)

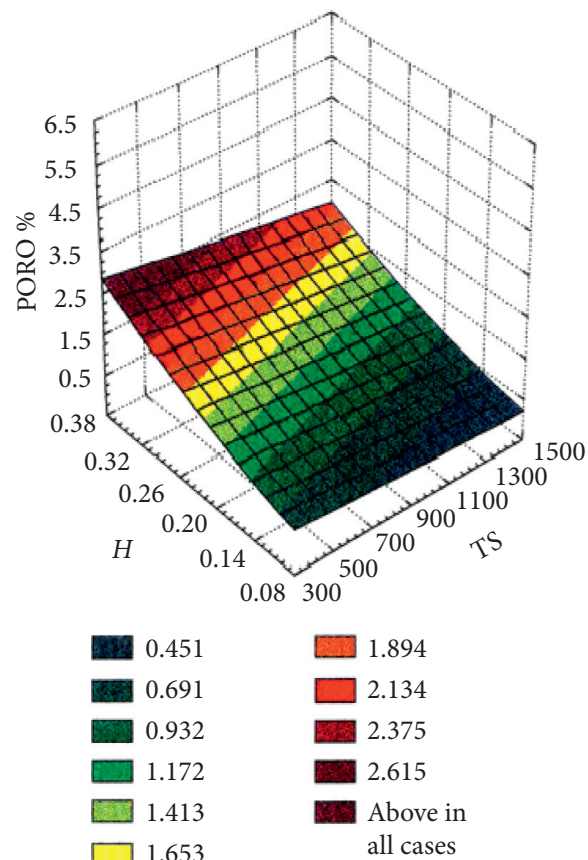

(b)

Figure 7: (a) Porosity-hydrogen-DAS relationship [27]. (b) Porosity-hydrogen-solidification time relationship [27].

total surface porosity is accompanied by a marked reduction in the alloy strength parameters, i.e., ultimate tensile strength (UTS), yield strength (YS), and fatigue life. The decrease in properties in Figure 14may be interpreted in terms of the high stress concentration at the pore surfaces resulting in a stress gradient between the sample surface and the specimen center as displayed in Figure 11for fatigue-tested samples [33].
3.2. Intermetallics. Figure 15 shows the solidification curve of $\mathrm{B} 319+0.8 \% \mathrm{Fe}$ revealing the temperatures of the precipitation of the three types of Fe-based intermetallics. Obviously, it is expected that as the solidification temperature decreases, the size and distribution of the precipitated Fe-phases will decrease. The backscattered electron image in Figure 16(a)illustrates the effectiveness of $\beta$-platelets in 


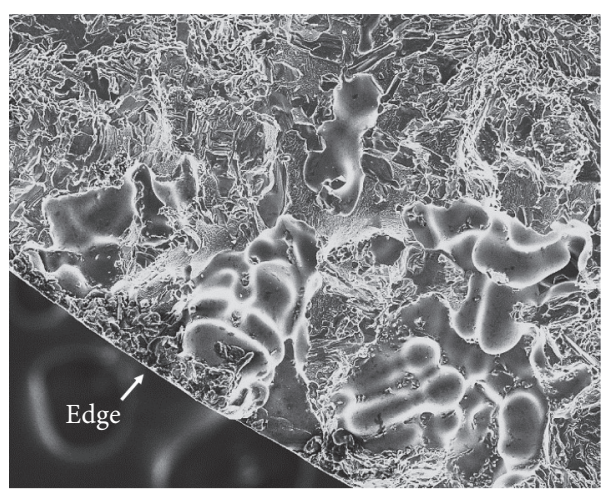

(a)

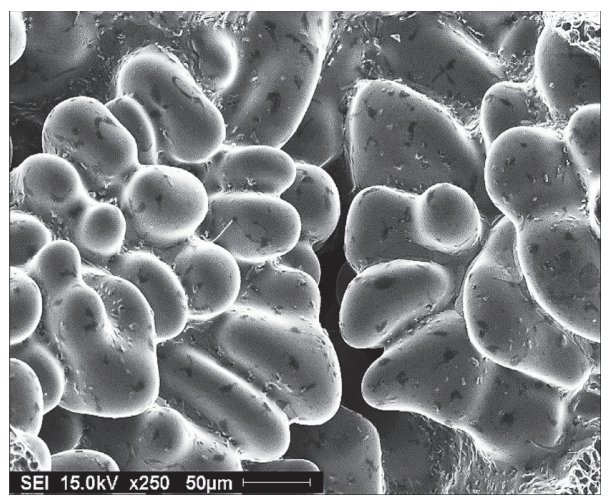

(c)

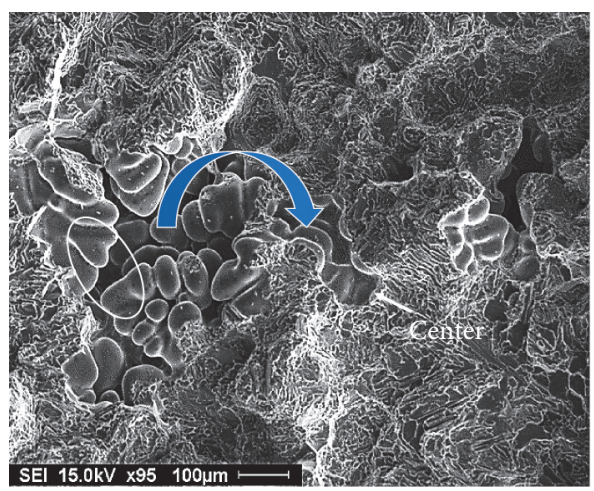

(b)

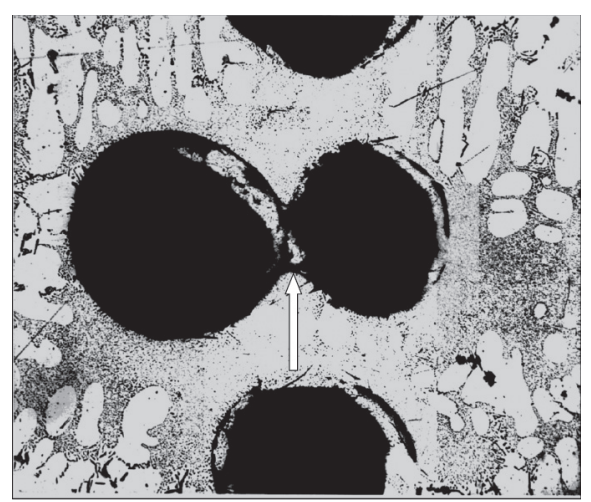

(d)

FIgURE 8: Fracture surface of fatigue tested samples: (a) presence of disconnected pores at the sample surface, (b) shrinkage porosity at the center of the samples, (c) high magnification micrographs of the dendrites in (b), (d) joining of pores during loading-loading axis is normal to the polished surface.

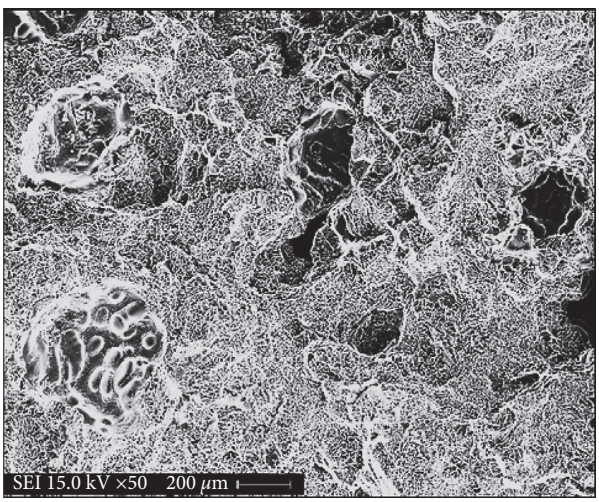

(a)

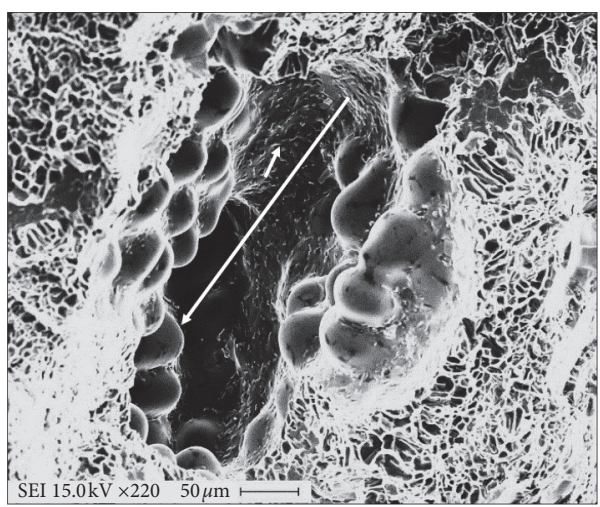

(c)

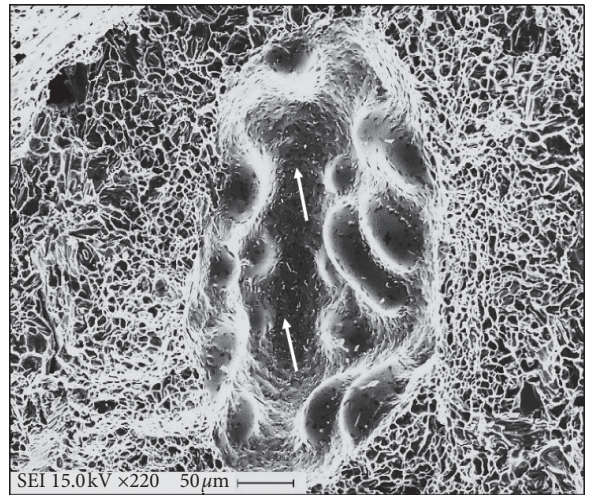

(b)

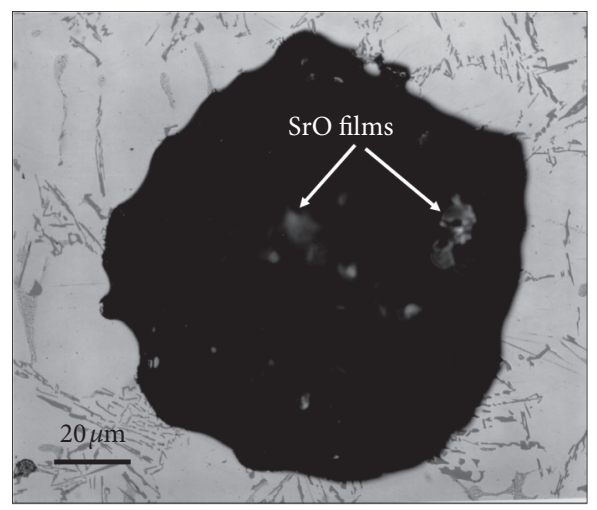

(d)

Figure 9: Continued. 


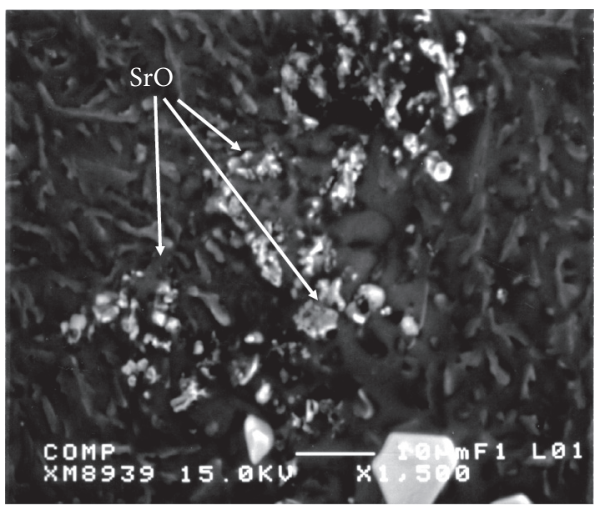

(e)
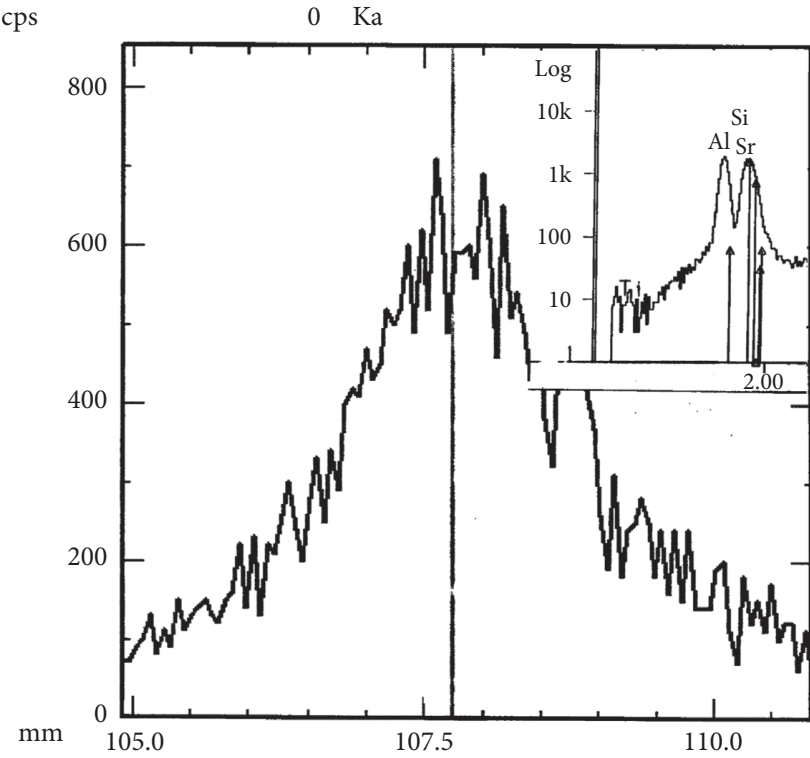

(f)

Figure 9: Porosity formation in Sr-modified A356 alloy: (a) general distribution of porosity $(0.25 \mathrm{ml} / 100 \mathrm{~g} \mathrm{Al}),(\mathrm{b}, \mathrm{c}) \mathrm{H}_{2}=\sim 0.4 \mathrm{ml} / 100 \mathrm{~g} \mathrm{Al}$, (d) optical micrograph shows presence of $\mathrm{SrO}$ particles at the bottom of the pore, (e) backscattered electron image of SrO particles viewed in a gas pore-bright spots ( $\mathrm{Sr}$ atomic number is 38 whereas $\mathrm{Al}$ atomic number is 13 ), (f) $\mathrm{O}_{2}$-X-ray spectrum obtained from the particles in (e). Average dendrite arm spacing is about $25 \mu \mathrm{m}$.

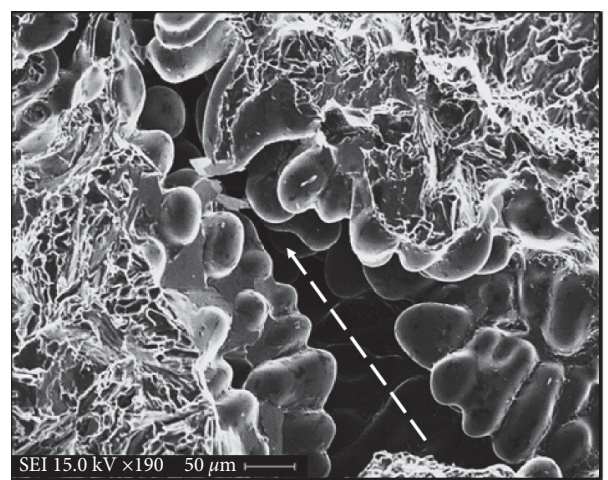

(a)

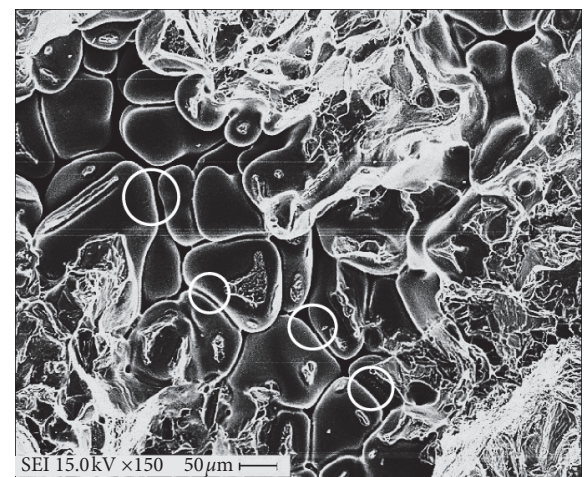

(b)

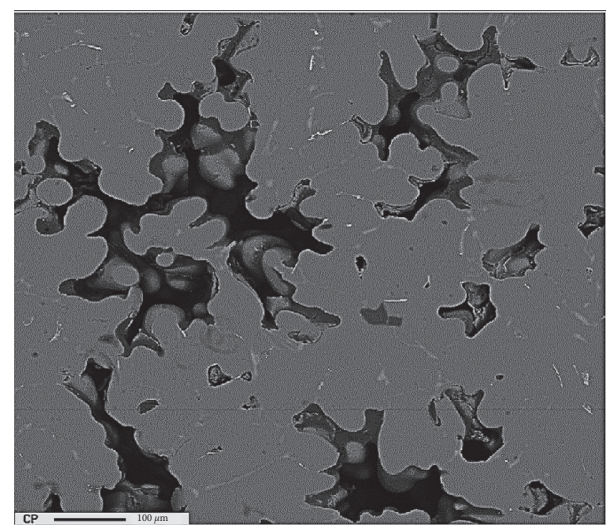

(c)

Figure 10: Formation of shrinkage cavities in Sr-modified A356 alloy: (a) tensile test bar $\left(H_{2}=\sim 0.4 \mathrm{ml} / 100 \mathrm{~g}\right.$ Al), (b) fatigue test bar $\left(H_{2}=0.4 \mathrm{ml} / 100 \mathrm{~g} \mathrm{Al}\right)$, (c) sand casting of non-modified A356 alloy $\left(H_{2}<0.1 \mathrm{ml} / 100 \mathrm{~g} \mathrm{Al}\right)$, average dendrite arm spacing is $\sim 120 \mu \mathrm{m}$. 


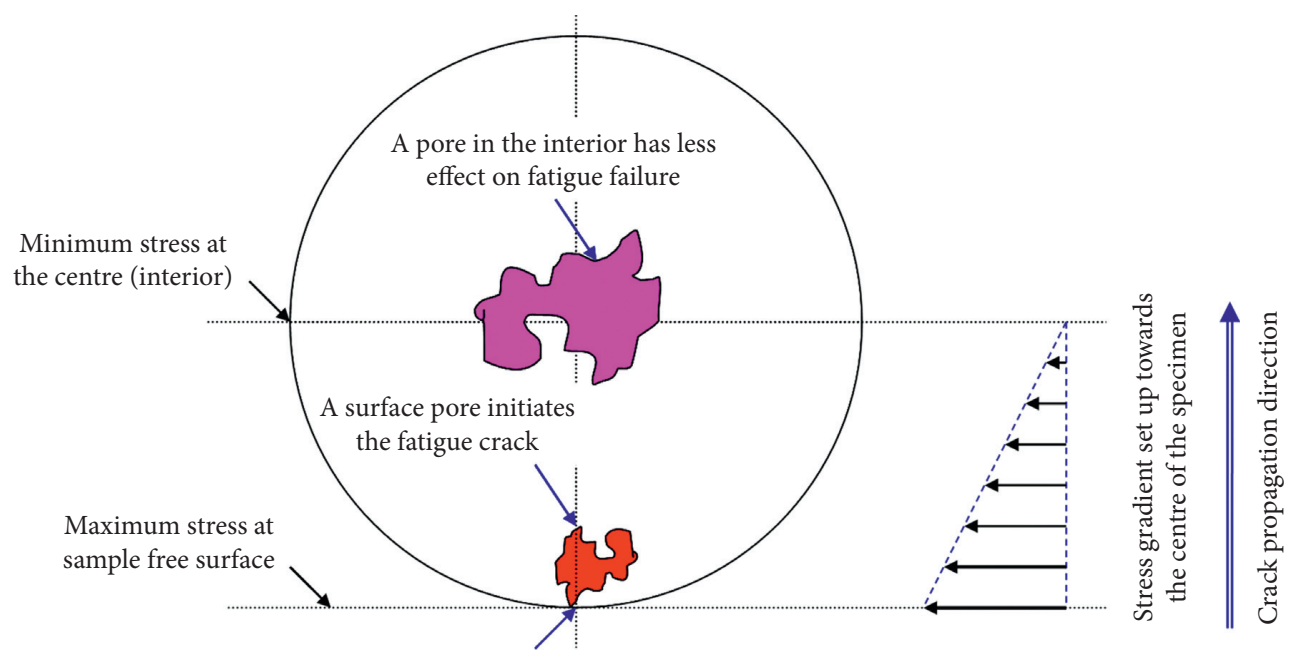

High stress concentration at the surface pore located at the edge

FIGURE 11: Stress concentration and its gradient at the pore surface [31].

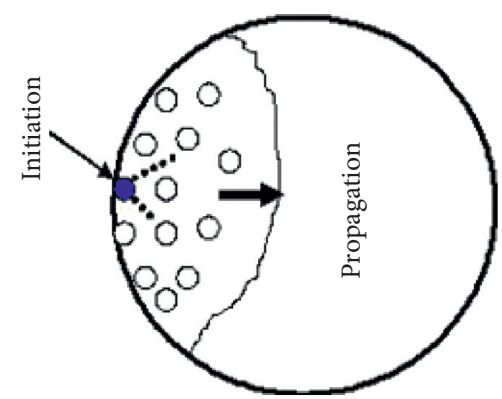

(a)

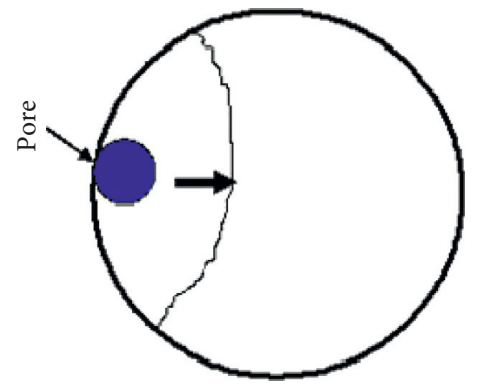

(b)

FIgURE 12: Fatigue crack initiation sites [32]. Thin black arrows point to crack initiation site whereas thick arrow indicates the crack propagation direction.

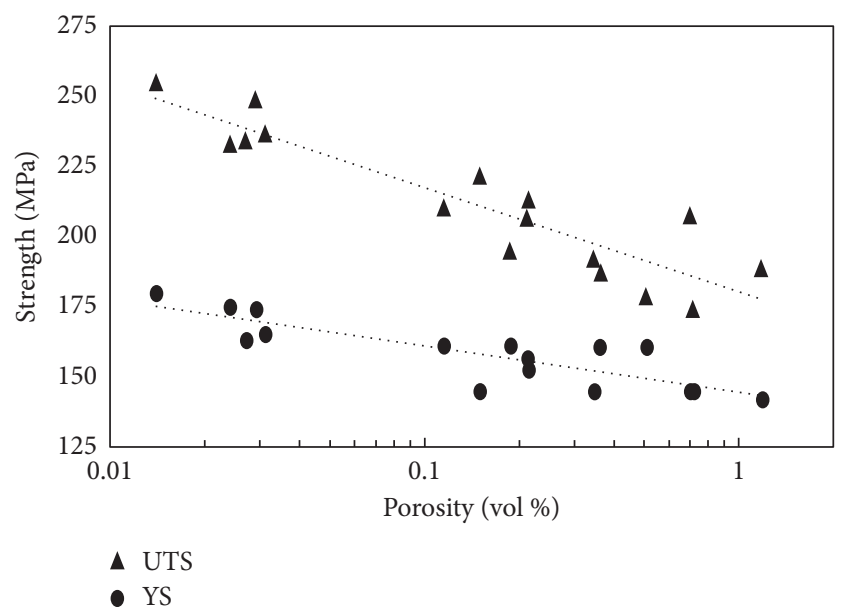

FIGURE 13: Effect of porosity volume fraction on the tensile properties of A356 alloy in the T6 condition [27]. restricting the flow of the liquid metal leading to formation of a coarse shrinkage cavity. Although precipitation of $\alpha-\mathrm{Al}_{12}(\mathrm{Fe}, \mathrm{Mn})_{3} \mathrm{Si}_{2}$ phase takes place at a temperature lower than that of $\beta-\mathrm{Al}_{5} \mathrm{FeSi}$ phase (Figure $16(\mathrm{~b})$ ), it does not seem to have an effective role in porosity formation due to branching which would facilitate the motion of the liquid metal between the script arms as displayed in Figure 16(c).

At $540^{\circ} \mathrm{C}$, a part of $\beta-\mathrm{Al}_{5} \mathrm{FeSi}$ transforms into $\pi-\mathrm{Al}_{8} \mathrm{Mg}_{3} \mathrm{FeSi}_{6}$ in the form of a group of short platelets as shown in Figure 16(d), as was confirmed from the associated EDS spectrum displayed in Figure 16(e). Due to narrow distances between the $\pi$-platelets (about $10 \mu \mathrm{m}$ in length and $1 \mu \mathrm{m}$ in thickness) compared to the original $\beta$-phase platelets ( $\sim 100 \mu \mathrm{m}$ in length and $5 \mu \mathrm{m}$ in thickness) coupled with the reduction in the liquid metal fluidity, pockets of small voids may form within the $\pi$-phase platelets as illustrated in Figure 16(d), white circles. It should be mentioned here that not only are $\beta$-platelets an effective site for causing shrinkage cavities, but also other intermetallics such as rare earthbased intermetallics were found to be capable of restricting the flow of the liquid metal as depicted in Figure 16. 


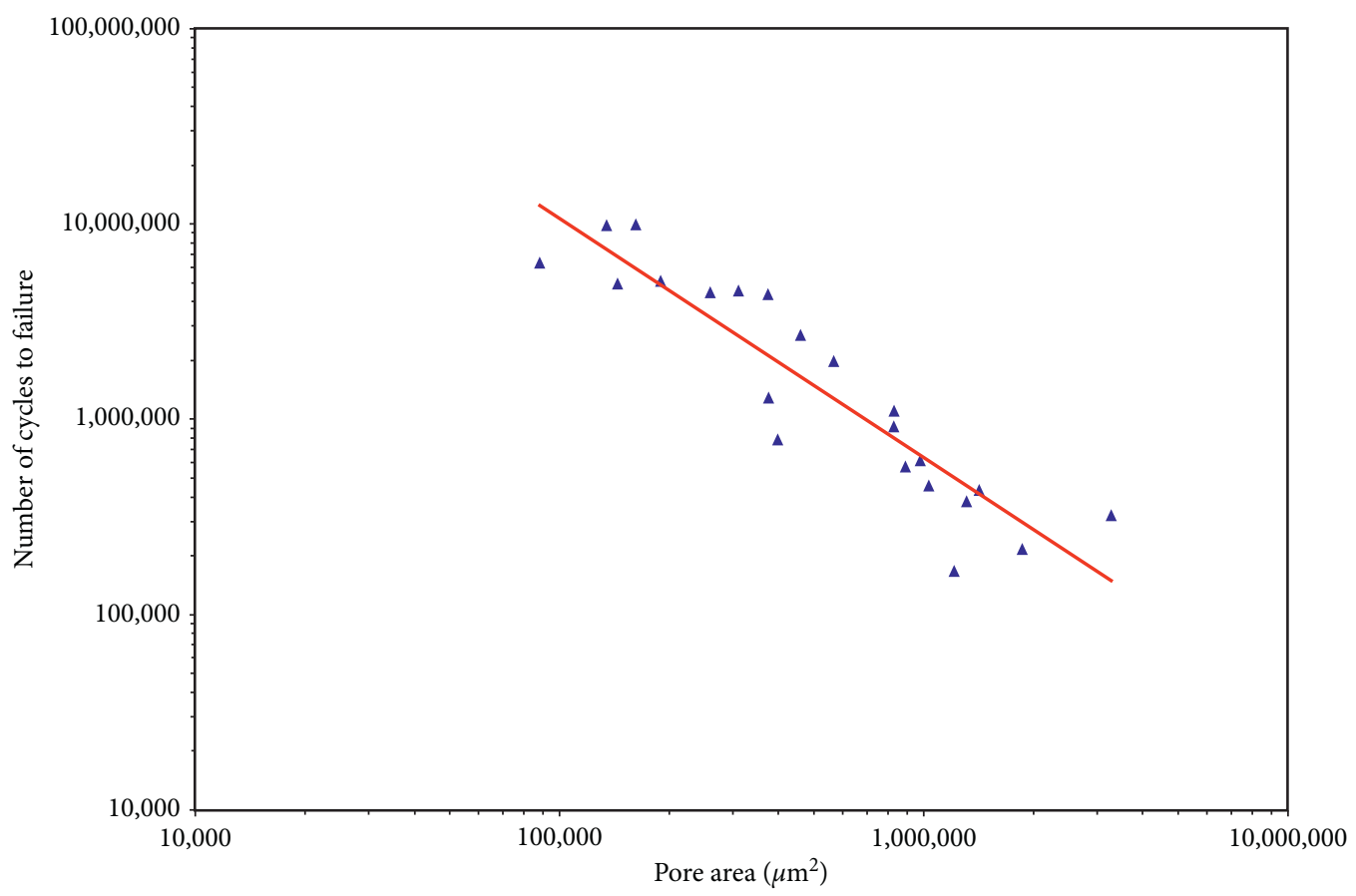

Figure 14: Effect of porosity volume fraction on the fatigue life of A356 alloy in the T6 condition [33].

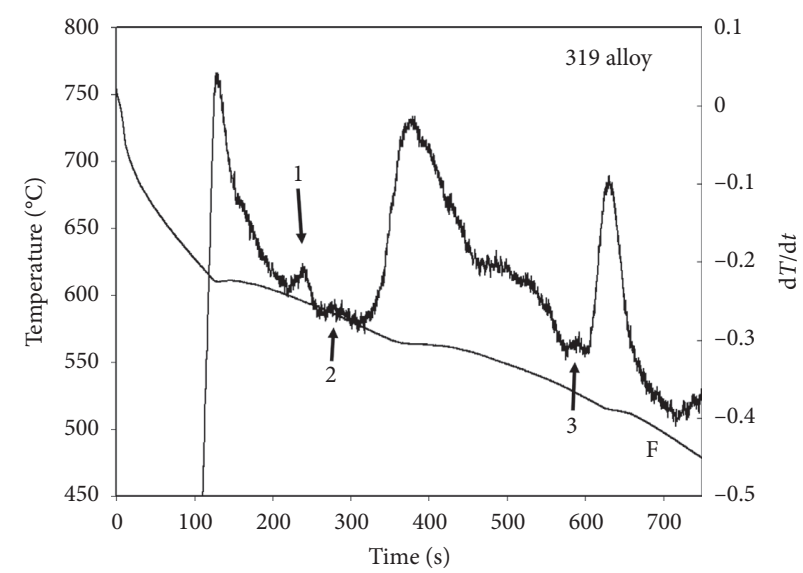

Figure 15: Solidification curve of $\mathrm{B} 318+0.8 \% \mathrm{Fe}$ : (1) precipitation of $\beta$-phase $\left(\sim 595^{\circ} \mathrm{C}\right),(2)$ precipitation of $\alpha$-Fe $\left(\sim 580^{\circ} \mathrm{C}\right)$, (3) partial transformation of $\beta$-Fe to $\pi$ - $\mathrm{Fe}\left(540^{\circ} \mathrm{C}\right)$.

In addition to platelet-shaped intermetallics, high temperature melting compounds were found to nucleate gas and shrinkage cavities. In this section, examples obtained from welldegassed molten alloys will be reviewed. Figure 17(a) shows the precipitation of $\mathrm{Mg}_{2} \mathrm{Sn}$ compound in branched star-like form within the $\alpha$ - $\mathrm{Al}$ dendrites. Considering the melting point of this compound is about $770^{\circ} \mathrm{C}[34]$ and the $\alpha$ - $\mathrm{Al}$ network precipitates at about $615^{\circ} \mathrm{C}$ (Figure 15), thus the $\alpha$-Al dendritic structure was precipitated on the pre-existing phase $\mathrm{Mg}_{2} \mathrm{Sn}$ phase particles leading to formation of a large shrinkage cavity $\left(H_{2}<0.1 \mathrm{ml} / 100 \mathrm{~g} \mathrm{Al}\right)$.
Another feature to be considered is the precipitation of $\mathrm{Al}_{2} \mathrm{Si}_{2} \mathrm{Sr}$ phase in the form of tetrahedral pyramids at the bottom of a cavity (Figures 17(b) and 17(c)). Since the melting point of $\mathrm{Al}_{4} \mathrm{Sr}$ phase is $1034^{\circ} \mathrm{C}$, it is suggested that the reaction between $\mathrm{Al}_{4} \mathrm{Sr}$ and the Si resulted in formation of the present compound. However, the exact precipitation temperature is not yet determined. In this case, the size of the pore depends on the number of the $\mathrm{Al}_{2} \mathrm{Si}_{2} \mathrm{Sr}$ particles and their occupied size as exhibited in Figure 17(d).

Mahmoud et al. [35, 36] reported that the shape of rare earth (RE) based intermetallics depends on the Ti/RE ratio. 


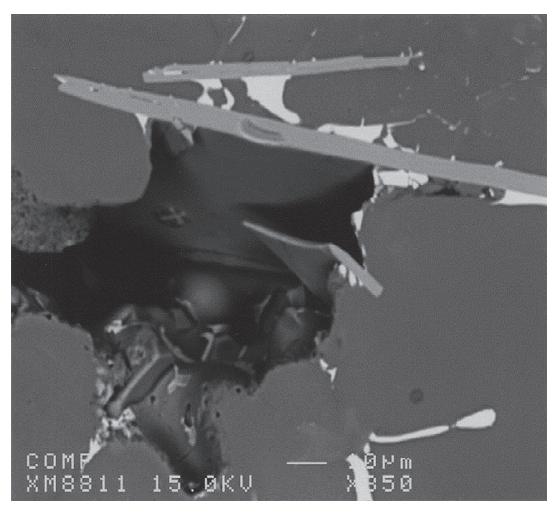

(a)

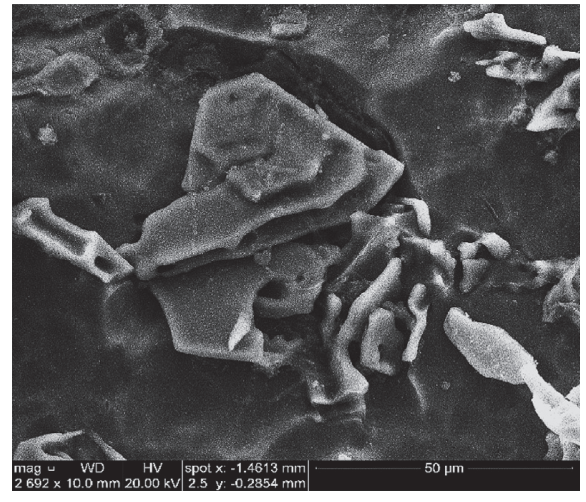

(c)

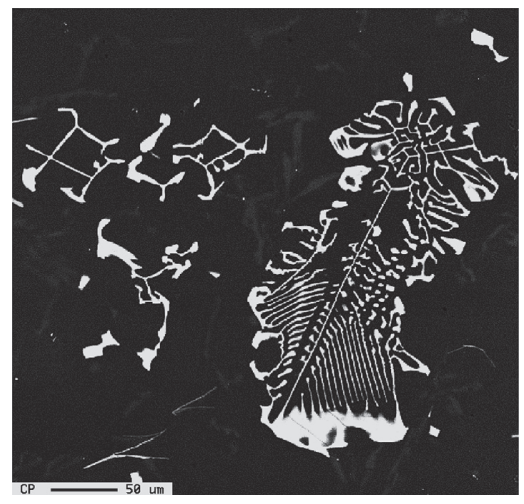

(b)

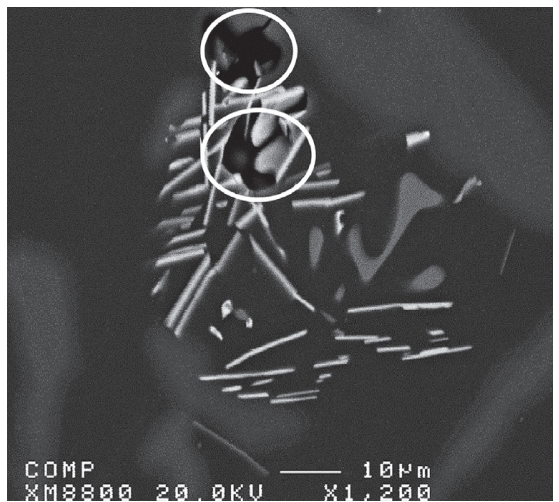

(d)

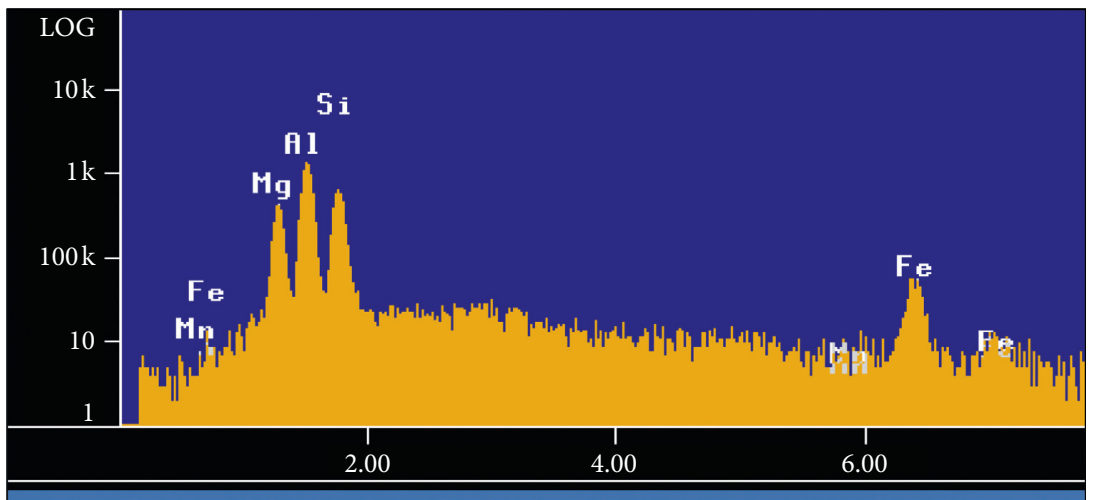

(e)

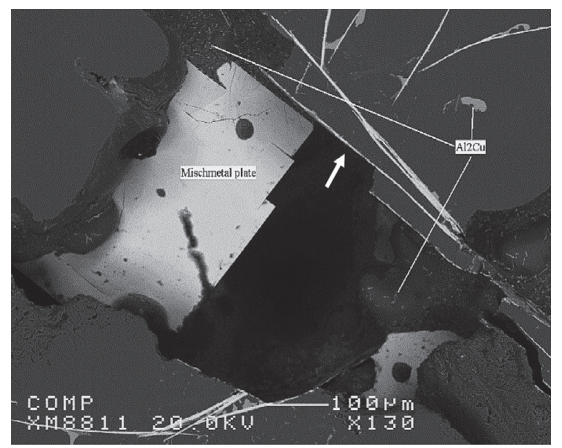

(f)

FIGURE 16: Backscattered electron images of shrinkage porosity in B319 + 0.8\%Fe showing the following: (a) $\beta$-platelets, (b) $\alpha$-Fe-polished sample, (c) $\alpha$-Fe-fracture surface, (d) $\pi$-Fe, and (e) EDS spectrum corresponding to (d) showing reflections due to $\mathrm{Al}, \mathrm{Si}, \mathrm{Mg}$, and $\mathrm{Fe}$ and (f) rare earth metal platelet-white arrow indicates the restriction of pore growth same as $\beta$-Fe platelets. 


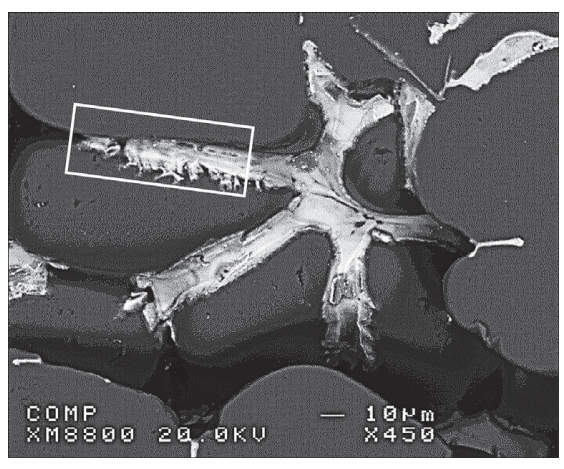

(a)

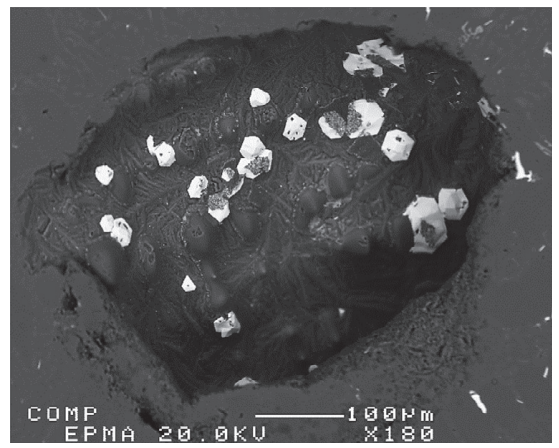

(d)

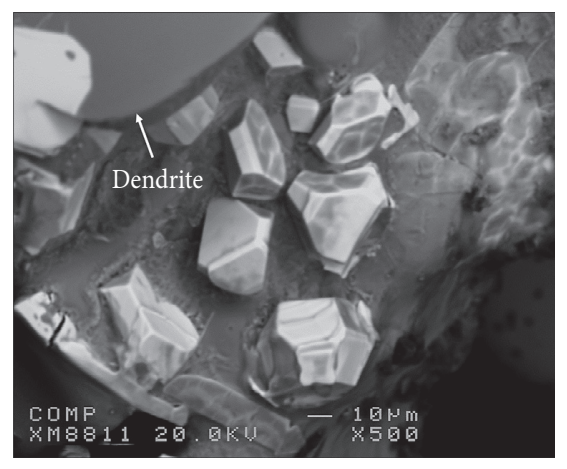

(b)

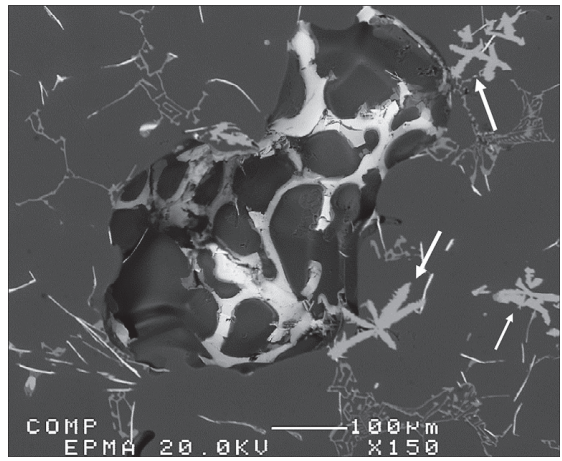

(e)

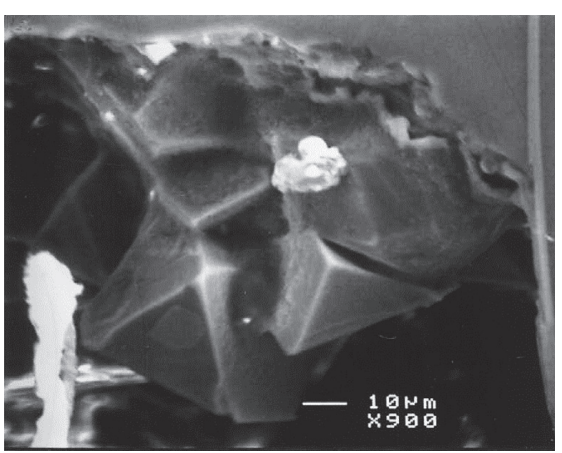

(c)

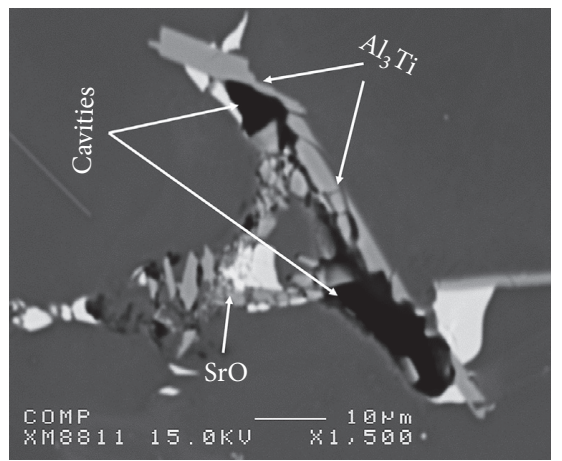

(f)

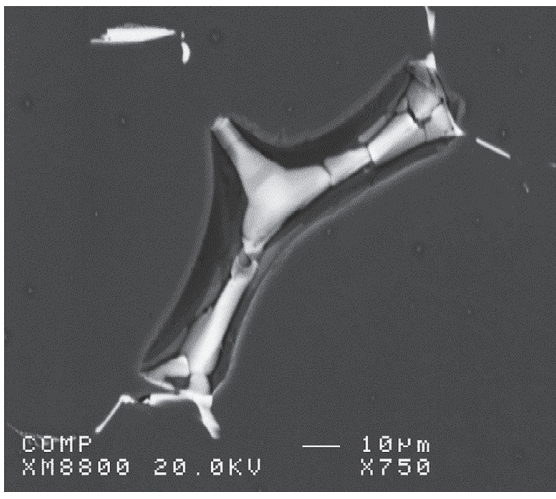

(g)

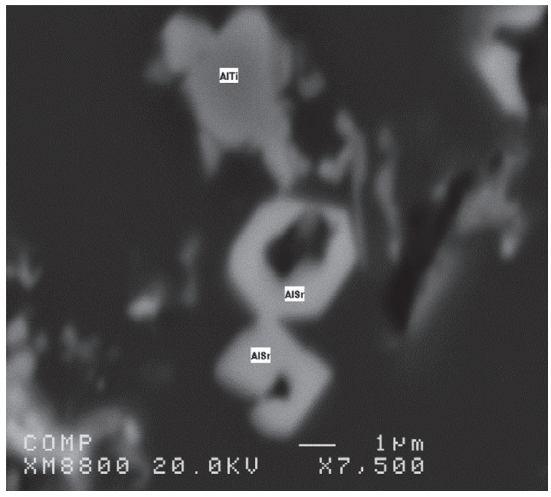

(h)

FiguRE 17: Backscattered electron images of porosity occurring due to precipitation of high temperature compounds: (a) $\mathrm{Mg}_{2} \mathrm{Sn}$ particles; note: the presence of $\mathrm{Mg}_{2} \mathrm{Sn}$ arm lying within the dendrites (white rectangle), (b-d) $\mathrm{Al}_{2} \mathrm{Si}_{2} \mathrm{Sr}$ particles, (e) high Ti-containing $\mathrm{RE}$ intermetallic-note the absence of cavities around the star-like particles as indicated by the white arrows, (f) segregation of $\mathrm{Al}_{3} \mathrm{Ti}$ phase particles, (g) precipitation of massive AlTiBSr phase particles, (h) precipitation of both AlTi and AlSr particles.

In the case this ratio is $<1, \mathrm{RE}$-intermetallics precipitate in the form of thin platelets as shown in Figure 17(e). However, when $\mathrm{Ti}>\mathrm{RE}$, the RE-intermetallics precipitate in the form of gray sludge (star-like form) as demonstrated in Figure $17(\mathrm{e})$ where $\mathrm{Ti}$ is about 7 at. $\%$ and $\mathrm{Li}$ is about 4 at $\%$. In this case, high Ti-containing RE phase particles are joined together at the bottom of a large pore. In contrast, particles outside this pore show no sign of micro/macro-porosity associated with their presence, indicating that the precipitation temperature of this phase is high enough to render the molten metal good fluidity to fill up the spacing between the branches.

Another aspect to be considered is the excess use of grain refiner, in particular $\mathrm{Al}-10 \% \mathrm{Ti}$ that leads to formation of $\mathrm{Al}_{3}$ Ti phase in the form of clusters of short platelets as shown in Figure 17(f). As a result, several micro-pores may occur between these particles.

In the case that the alloy was grain refined using a master alloy containing $\mathrm{Ti}$ and $\mathrm{B}$, it is possible that these two elements may react with $\mathrm{Sr}$ in modified alloys forming a 


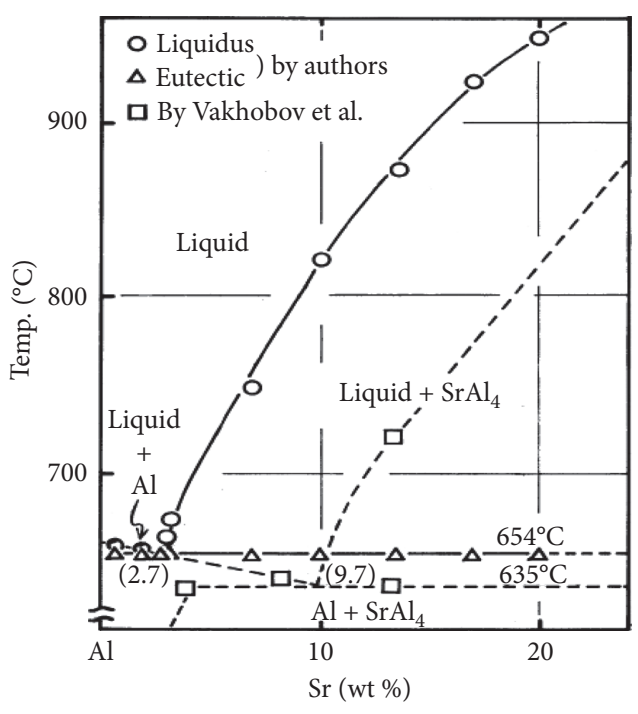

(a)

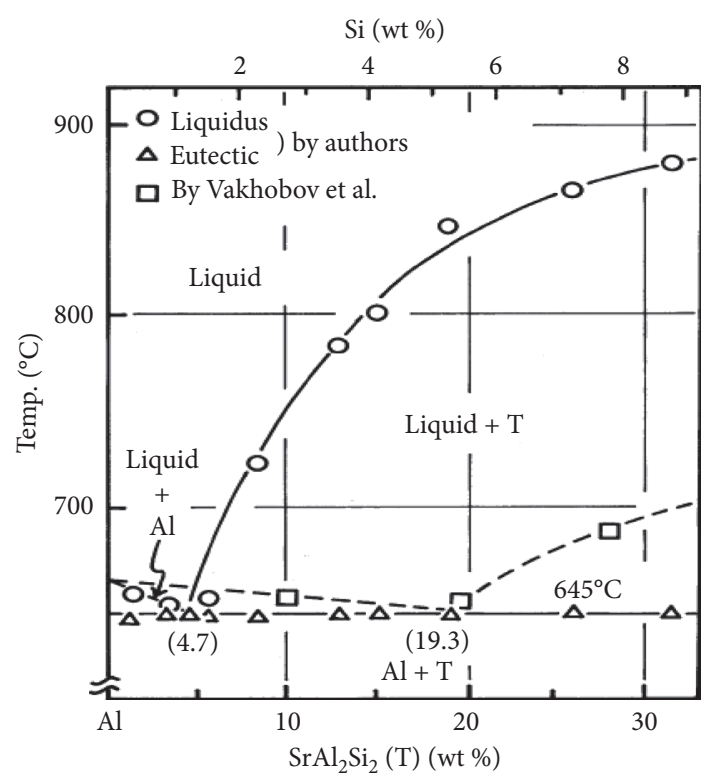

(b)

Figure 18: (a) The aluminum end phase diagram of Al-Sr binary system, (b) the aluminum end phase diagram of $\mathrm{Al}_{-}-\mathrm{SrAl}_{2} \mathrm{Si}_{2}(\mathrm{~T})$ quasibinary system [37].

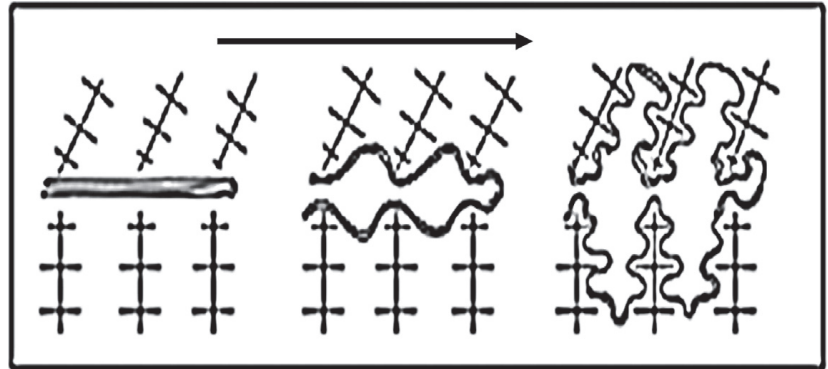

FIGURE 19: Mechanism of bifilm-porosity formation proposed by Dispinar and Campbell [43]. Arrow indicates the progress of solidification.

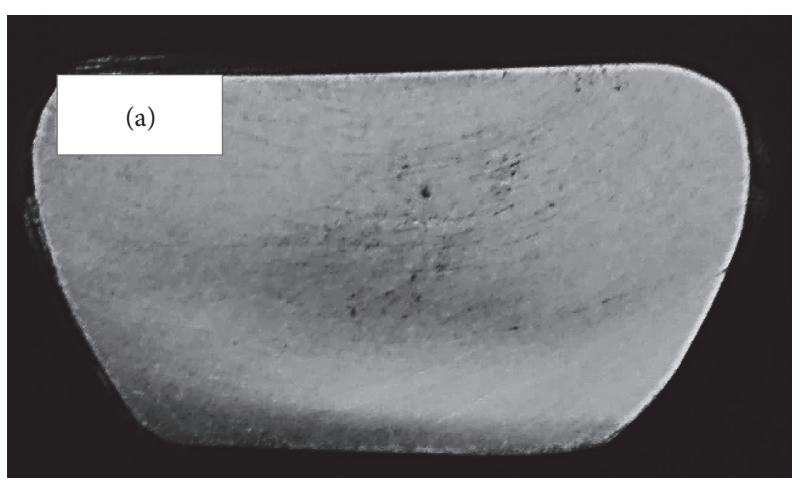

(a)

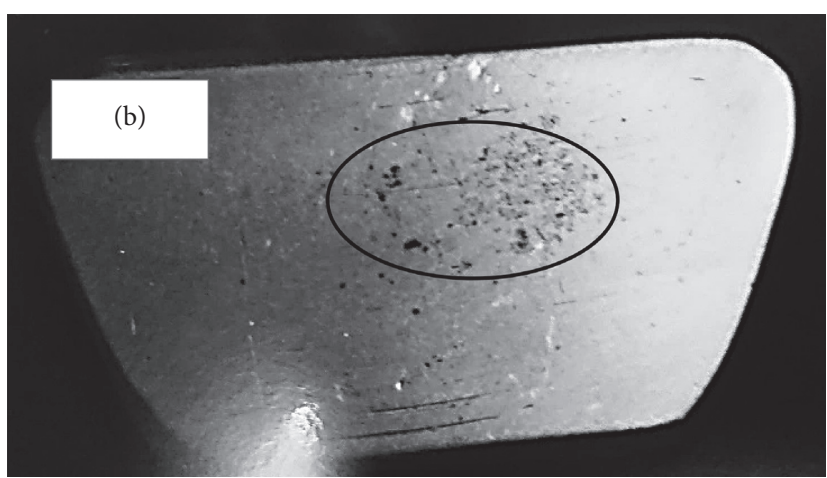

(b)

Figure 20: RPT samples obtained from alloy A356 melt after (a) degassing and (b) addition of $200 \mathrm{ppm}$ Sr. Note: the porosity in the circled area in (b). 


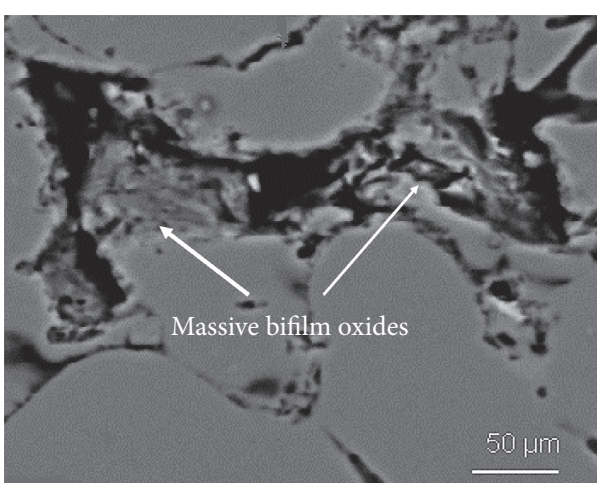

(a)

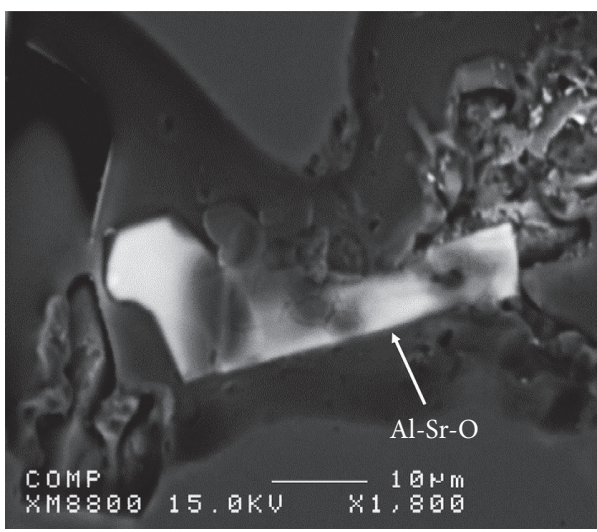

(c)

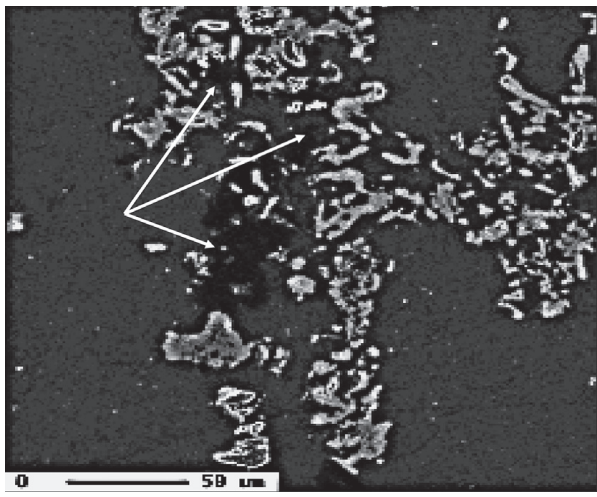

(e)

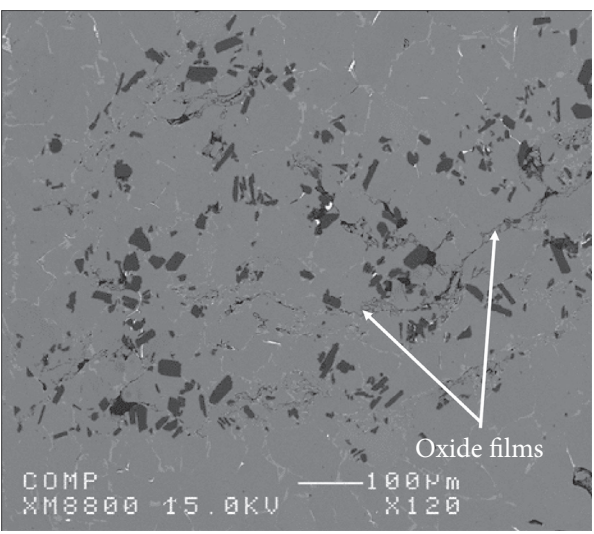

(g)

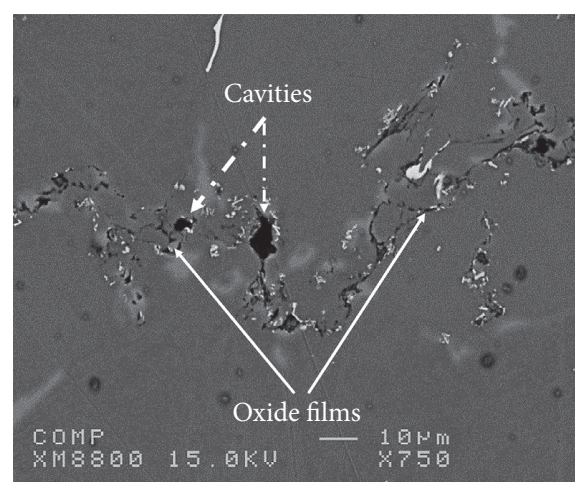

(b)

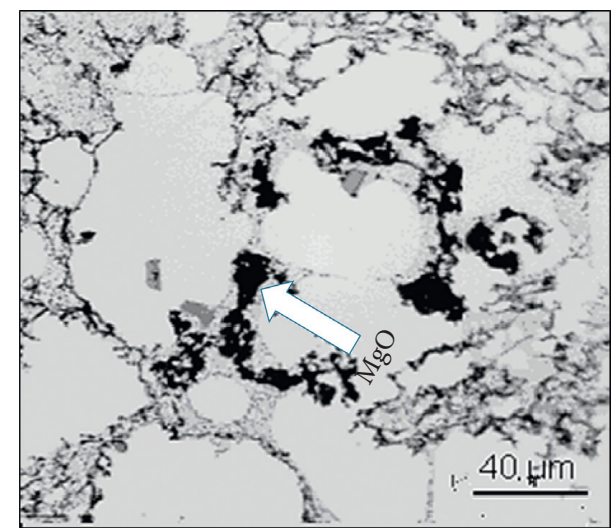

(d)

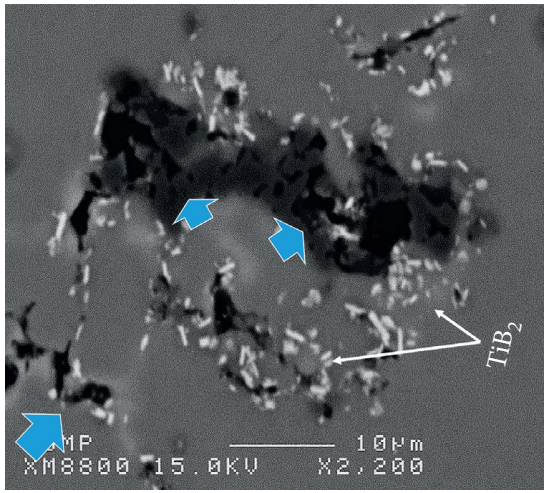

(f)

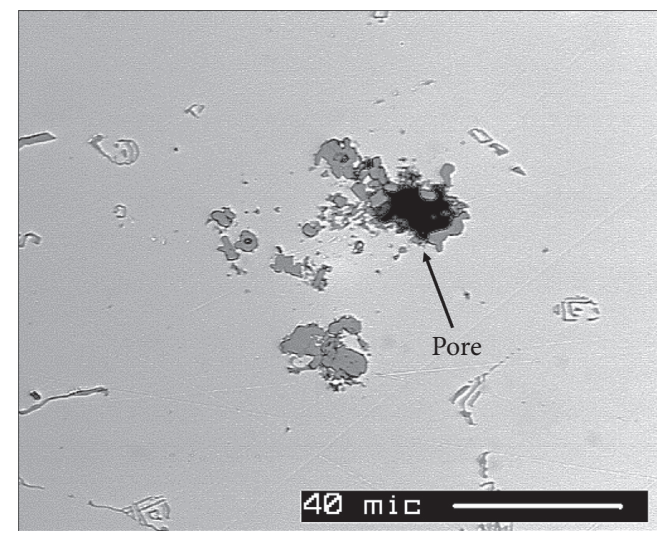

(h)

Figure 21: Backscattered electron images of porosity formation in B319 alloy: (a) bifilm oxides, (b) thin films of oxides, (c) Al-Sr-O oxide platelet, (d) optical micrograph of $\mathrm{MgO}$, (e) $\mathrm{x}$-ray image showing general distribution of $\mathrm{O}_{2}$ in the matrix-white arrows point to cavities, (f) precipitation of $\mathrm{TiB}_{2}$ particles, $(\mathrm{g})$ and $(\mathrm{h})$ addition of $\mathrm{Al}_{2} \mathrm{O}_{3}$ particulates/dispersoids. 
complex compound AlTiBSr which apparently has a tendency to form cavities as seen in Figure $17(\mathrm{~g})$, similar to those shown in Figure 17(f). Figure 17(h) offers another possibility for both AlTi and AlSr to be potential sources for porosity formation.

According to Sato et al. [37] and Vakhobov et al. [38], the aluminum corner of Al-Si-Sr ternary alloy system was investigated by means of inverse rate thermal analysis, with identification by $\mathrm{x}$-ray diffraction, EPMA analysis, and microscopic observation. A ternary compound $\mathrm{SrAl}_{2} \mathrm{Si}_{2}$, named "T," exists in this ternary system and the Al-T line is considered as a quasibinary system with a eutectic point at $1.1 \% \mathrm{Si}, 2.4 \% \mathrm{Sr}, 645^{\circ} \mathrm{C}$. The aluminum corner is divided into two regions by the Al-T quasibinary system. A ternary eutectic point was determined to locate at $575^{\circ} \mathrm{C}, 13.1 \% \mathrm{Si}$, $0.03 \% \mathrm{Sr}$, which is very close to the Al-Si binary eutectic point. The modification effect of small amount of strontium addition on Al-Si alloys can be regarded to be due to the formation of a fine ternary eutectic structure. In the Al$\mathrm{SrAl}_{4}$-T region, a ternary eutectic point was found to locate at $643^{\circ} \mathrm{C}$ with $1.7 \% \mathrm{Si}, 2.4 \% \mathrm{Sr}$. The solubility of strontium and silicon in aluminum was examined along three ray sections. The greatest solubility is shown to occur along the $\mathrm{SrSi}_{2}-\mathrm{Al}$ (T phase) quasibinary section at $\mathrm{Sr}: \mathrm{Si}=1: 2$. It is found that the $\mathrm{SrAl}_{2} \mathrm{Si}$ compound melts at $1010 \pm 10^{\circ} \mathrm{C}$. This compound forms constitutional diagrams of the eutectic type with aluminum, silicon, strontium, and also $\mathrm{SrSi}_{2}$ and $\mathrm{SrAl}_{4-}$ compounds as shown in Figure 18.

3.3. Oxide Films and Dispersoids. Atakav et al. [39] investigated the effect of $\mathrm{Sr}$ addition on the melt cleanliness of A356 alloy. Reduced pressure test (RPT) was used to assess melt quality change and it was found that cleanliness was increased due to the fading of Sr. Characterization of the effect of melt treatments on melt quality in $\mathrm{Al}-7 \mathrm{wt} \% \mathrm{Si}-\mathrm{Mg}$ alloys was investigated by Uludag et al. [40] who found that, in both degassed and non-degassed melts, $\mathrm{Sr}$ additions degraded the melt quality significantly. Another source to be considered is oxide films, mainly $\mathrm{Al}_{2} \mathrm{O}_{3}$ and $\mathrm{SrO}$ [40-44]. Dispinar and Campbell [45] proposed the concept of bifilms defined as folding/unfolding and furling/unfurling mechanism. According to the authors, the bifilm index range is defined as follows [46]: $0-25 \mathrm{~mm}$ : best quality, $25-50 \mathrm{~mm}$ : good quality, $50-100 \mathrm{~mm}$ : average quality, $100-150 \mathrm{~mm}$ : bad quality > $150 \mathrm{~mm}$ : do not cast. An example of bifilm-porosity formation mechanism is exhibited in Figure 19. Figure 20shows an example of RPT test samples obtained from A356 alloy melts in the present study after (a) degassing, and (b) degassing plus addition of $200 \mathrm{ppm} \mathrm{Sr}$, where the development of increased porosity may be observed due to the presence of $\mathrm{SrO}$.

In this section, B319 alloy was used without degassing. The melt was held at $780^{\circ} \mathrm{C}$ for $3-4 \mathrm{~h}$. In order to avoid particle sedimentation, the melt was mechanically stirred from time to time. Porosity formation was examined using RPT technique. Figure 21(a)shows a good example of socalled bifilms as described by Dispinar and Campbell [45] and Campbell [46] in their investigations. In this case, pores are massive with irregular shape. However, this type of oxide was not observed in all the examined samples. It was seen following vigorous mechanical stirring of the melt. Oxide films in the form of long strings passing randomly throughout the matrix (solid arrows) were more commonly observed as shown in Figure 21(b)creating several micro-porosities $<10 \mu \mathrm{m}$ in length (broken arrows).

Strontium based oxides were often seen in the form of thin platelets within the shrinkage cavities as displayed in Figure 21(c). Although the exact composition could not be confirmed, x-ray imaging revealed the presence of Al, Sr, and $\mathrm{O}$ in this plate. As shown in Table 1, the present B319 alloy contains about $0.3 \% \mathrm{Mg}$. As a result, $\mathrm{Mg}$ could be oxidized forming $\mathrm{MgO}$ as displayed in Figure 21(d)tangled with other oxide films. Since the atomic number of $\mathrm{MgO}$ is close to $\mathrm{Al}$, an optical microstructure was used to demonstrate such a complex situation. Figure 21(e)illustrates the $\mathrm{O}_{2}$ distribution in a similar area.

Grain refining using $\mathrm{Al}-5 \% \mathrm{Ti}-1 \% \mathrm{~B}$ is commonly employed in the aluminum industry (approximately $0.1-0.15 \% \mathrm{Ti})$. The master alloy decomposes into $\mathrm{Al}_{3} \mathrm{Ti}+\mathrm{TiB}_{2}$ phases. The $\mathrm{TiB}_{2}$ particles are ultra-fine ( 300-500 nm) which make them very suitable for grain nucleation, i.e., refining as shown in Figure 21(f). Exceeding the proper amount would lead to formation of high density of the $\mathrm{TiB}_{2}$ particles which would restrict the fluid motion and hence create spongy porosity (see blue arrows showing a large pore surrounded by tiny ones). Another example is depicted in Figure 21(g)where $\mathrm{Al}_{2} \mathrm{O}_{3}$ dispersoid particles were added to harden the alloy. During mechanical stirring, the aluminide particles tangled with the oxide films. If the $\mathrm{Al}_{2} \mathrm{O}_{3}$ particles are well dispersed, they only form microporosity at the particle/matrix interface. Porosity formation only happens when the $\mathrm{Al}_{2} \mathrm{O}_{3}$ particles are clustered/segregated together preventing the flow of the liquid metal as illustrated in Figure 21(h).

\section{Conclusions}

In this article, the different sources of the formation of porosity in Al-Si castings were discussed, mainly due to hydrogen level, high stress precipitation in the form of intercepted platelets or compounds, and the type of oxide films. The following conclusions have been drawn:

(1) The $\beta$-Fe, $\pi$-Fe, and low Ti-rare earth intermetallics platelets are very effective in restricting the flow of molten metal leading to formation of shrinkage cavities, whereas $\alpha$-Fe is comparably less active.

(2) Precipitation of high temperature compounds such as $\mathrm{Al}_{2} \mathrm{Si}_{2} \mathrm{Sr}, \mathrm{MgSn}, \mathrm{Al}_{3} \mathrm{Ti}$, or $\mathrm{TiB}_{2}$ could also be sites for porosity formation in the form of pockets or spongy-like. The size of pores in this case depends on the number of segregated or clustered compound particles.

(3) Oxide films $\left(\mathrm{Al}_{2} \mathrm{O}_{3}, \mathrm{MgO}, \mathrm{SrO}\right)$ in the form of branched strings or bifilms are strong candidates for 
creating micro-porosity compared to those (macroporosity) in 1 and 2.

(4) Strontium oxides appear in the form of thin platelets, dispersed particles, or thin films.

(5) Increasing the gas porosity balances a part of the volumetric change from liquid to solid state and thus the magnitude of shrinkage cavities, in particular in sand castings.

(6) Alloy mechanical properties depend on the location of the pores in the casting and their sizes. Some of the fine pores tend to join together under the applied load to form coarser ones.

\section{Data Availability}

Data will be available upon request to the corresponding author.

\section{Conflicts of Interest}

The authors declare that they have no conflicts of interest.

\section{Acknowledgments}

The authors would like to thank Amal Samuel for enhancing the quality of the artwork used in the present article.

\section{References}

[1] A. M. Samuel and F. H. Samuel, "Various aspects involved in the production of low-hydrogen aluminium castings," Journal of Materials Science, vol. 27, no. 24, pp. 6533-6563, 1992.

[2] L. Kuchariková, E. Tillová, M. Uhríčik, and J. Belan, "Porosity formation and fatigue properties of $\mathrm{AlSiCu}$ cast alloy," MATEC Web of Conferences, vol. 157, pp. 1-9, 2018.

[3] A. Shafyei, S. H. M. Anijdan, and A. Bahrami, "Prediction of porosity percent in Al-Si casting alloys using ANN," Materials Science and Engineering: A, vol. 431, pp. 206-210, 2006.

[4] B. Dybowski, "The porosity description in hypoeutectic Al-Si alloys," Key Engineering Materials, vol. 682, p. 83, 2016.

[5] M. T. DiGiovanni, J. T. O. deMenezes, E. Cerri, and E. M. Castrodeza, "Influence of microstructure and porosity on the fracture toughness of Al-Si-Mg alloy," Journal of Materials Research and Technology, vol. 9, pp. 1286-1295, 2020.

[6] T. Ludwig, M. Di Sabatino, L. Arnberg et al., "Influence of oxide additions on the porosity development and mechanical properties of A356 aluminium alloy castings," Inter Metalcast, vol. 6, pp. 41-50, 2012.

[7] S. H. M. Anijdan, A. Bahrami, H. R. M. Hosseini, and A. Shafyei, "Using genetic algorithm and artificial neural network analyses to design an Al-Si casting alloy of minimum porosity," Materials \& Design, vol. 27, pp. 605-609, 2006.

[8] M. K. Tripathi, S. Ganguly, P. Dey, and P. P. Chattopadhyay, "Evolution of glass forming ability indicator by genetic programming," Computational Materials Science, vol. 118, pp. 56-65, 2016.

[9] Y. Wang, D. Neff, D. Schwam et al., "Optimization of permanent mold mechanical property test bars in A356 alloy using a new mold design," International Journal of Metalcasting, vol. 7, no. 3, pp. 25-38, 2013.
[10] N. S. Tiedje, J. A. Taylor, and M. A. Easton, "A new multi-zone model for porosity distribution in Al-Si alloy castings," Acta Materialia, vol. 61, pp. 3037-3049, 2013.

[11] H. Ye, "An overview of the development of Al-Si-alloy based material for engine applications," Journal of Materials Engineering and Performance, vol. 12, pp. 288-297, 2003.

[12] M. Djurdjevic, R. Hasenbush, and J. Sokolowski, "Assessment of the hydrogen level in 319 aluminum alloy melts using the thermal analysis technique," Light Metals 2002, pp. 889-896, The Minerals, Metals, \& Materials Society, Warrendale, PA, USA, 2002.

[13] S. Akhtar, L. Arnberg, M. Sabatino, D. Dispinar, and M. Syvertsen, "A comparative study of porosity and pore morphology in a directionally solidified A356 alloy," International Journal of Metalcasting.vol. 3, no. 1, pp. 39-52, 2009.

[14] L. Elwin and E. Rooy, "Mechanisms of porosity formation in aluminum," Modern Casting, vol. 82, pp. 34-36, 1992.

[15] Q. T. Fang and P. N. Anyalebechi, "Effects of solidification conditions on hydrogen porosity formation in aluminum alloy castings," Light Metals 1988, pp. 477-486, The Minerals, Metals, \& Materials Society, Warrendale, PA, USA, 1988.

[16] Y. X. Gao, J. Z. Yi, P. D. Lee, and T. C. Lindley, "The effect of porosity on the fatigue life of cast aluminum-silicon alloys," Fatigue \& Fracture of Engineering Materials \& Structures, vol. 27, no. 7, pp. 59-570, 2004.

[17] E. Tillová, D. Závodská, L. Kuchariková, and M. Chalupová, "Study of bending fatigue properties of Al-Si cast alloy," Archives of Metallurgy and Materials, vol. 62, 2017.

[18] J. J. I. Mattos, A. V. Uehara, M. Sato, and I. Ferreira, "Fatigue properties and micromechanism of fracture of an AlSiMg0.6 cast alloy used in diesel engine cylinder head," Procedia Engineering, vol. 2, pp. 759-765, 2010.

[19] C. D. Ridgeway, K. Ripplinger, D. Detwiler, and A. A. Luo, AFS Proceedings of the 124th Metalcasting Congress, American Foundry Society, Cleveland, OH, USA, 2020.

[20] A. J. Koprowski, Q. Wang, P. Jones, and T. Gustafson, AFS Proceedings of the 124th Metalcasting Congress, American Foundry Society, Cleveland, OH, USA, 2020.

[21] D. Hoefert, AFS Proceedings of the 124th Metalcasting Congress, American Foundry Society, Cleveland, OH, USA, 2020.

[22] N. S. Tiedj, J. A. Taylor, and M. A. Easton, "Feeding and distribution of porosity in cast Al-Si alloys as function of alloy composition and modification," Metallurgical and Materials Transactions A, vol. 43, pp. 4846-4858, 2012.

[23] Bomem Inc, AlSCAN Version 2.2 User's Manual, Chapter 9, Bomem Inc., Quebec, Canada, 1991.

[24] Q. G. Wang, P. N. Crepeau, D. Gloria, and S. Valtierra, "Improvement of fatigue strength in aluminum castings," in Proceedings of the 2nd International Aluminum Casting Technology Symposium, pp. 209-218, ASM International, Columbus, OH, USA, May 2002.

[25] M. Tiryakioḡlu, "Solubility of hydrogen in liquid aluminium: reanalysis of available data," International Journal of Cast Metals Research, vol. 32, no. 2, pp. 1-4, 2020.

[26] G. Couturier and M. Rappaz, "Effect of volatile elements on porosity formation in solidifying alloys," Modelling and Simulation in Materials Science and Engineering, vol. 14, no. 2, pp. 253-271, 2006.

[27] G. Boudreault, A. M. Samuel, F. H. Samuel, and H. W. Doty, "Porosity formation in 319 aluminum alloy sand castings in relation to product quality for automotive applications," in Proceedings of the 36th Annual Conference of Metallurgists of CIM, pp. 369-384, Sudbury, Canada, August 1997. 
[28] T. Magnusson and L. Arnberg, "Density and solidification shrinkage of hypoeutectic aluminum-silicon alloys," Metallurgical and Materials Transactions A, vol. 32, pp. 2605-2613, 2001.

[29] M. Leitner, T. Leitner, A. Schmon, and K. Aziz, "Thermophysical properties of liquid aluminum," Metallurgical and Materials Transactions A, vol. A48, no. 5, 2017.

[30] V. B. Deev, E. S. Prusov, M. Shunqi et al., "The influence of the melt cooling rate on shrinkage behaviour during solidification of aluminum alloys," Materials Science and Engineering, vol. 537, Article ID 022080, 2019.

[31] H. R. Ammar, A. M. Samuel, and F. H. Samuel, "Porosity and the fatigue behavior of hypoeutectic and hypereutectic aluminum-silicon casting alloys," International Journal of Fatigue, vol. 30, no. 6, pp. 1024-1035, 2008.

[32] H. R. Ammar, A. M. Samuel, and F. H. Samuel, "Effects of surface porosity on the fatigue strength of AE425 and PM390 hypereutectic Al-Si casting alloys at medium and elevated temperatures," Materials Science and Engineering A, vol. 473, no. 1-2, pp. 58-64, 2008.

[33] H. R. Ammar, A. M. Samuel, and F. H. Samuel, "Effect of casting imperfections on the fatigue life of 319-F and A356-T6 Al-Si casting alloys," Materials Science and Engineering A, vol. 473, no. 1-2, pp. 65-75, 2008.

[34] M. Zamani, S. Seifeddine, and M. Aziziderouei, "The role of Sr on microstructure formation and mechanical properties of Al-Si-Cu-Mg cast alloy," Annual Meeting and Exhibition, Springer, Cham, Germany, 2013.

[35] M. G. Mahmoud, A. M. Samuel, H. W. Doty, and F. H. Samuel, "Role of heat treatment on the tensile properties and fractography of $\mathrm{Al}-1.2 \mathrm{Si}-2.4 \mathrm{Cu}$ and $\mathrm{Al}-8.0 \mathrm{Si}-2.4 \mathrm{Cu}$ cast alloys modified with $\mathrm{Ce}, \mathrm{La}$ and $\mathrm{Sr}$ addition," International Journal of Metalcasting, vol. 14, no. 1, pp. 218-242, 2020.

[36] M. G. Mahmoud, A. M. Samuel, H. W. Doty, and F. H. Samuel, "Effect of the addition of $\mathrm{La}$ and $\mathrm{Ce}$ on the solidification behavior of $\mathrm{Al}-\mathrm{Cu}$ and $\mathrm{Al}-\mathrm{Si}-\mathrm{Cu}$ cast alloys," International Journal of Metalcasting, vol. 14, no. 1, pp. 191206, 2020.

[37] E. Sato, N. Kono, H. Watanabe, and I. Sato, "Study on the phase diagram of Al-Si-Sr ternary alloy system," Journal of Japan Institute of Light Metals.vol. 35, no. 2, pp. 71-78, 1985.

[38] A. V. Vakhobov, I. N. Ganiev, and T. D. Djuraev, "Study on the phase diagram of Al-Si-Sr ternary alloy system," Journal of Japan Institute of Light Metals, vol. 7, p. 15, 1975.

[39] B. Atakav, Ö. Gürsoy, E. E. K. Tur, and D. Dispinar, "Sr addition and its effect on the melt cleanliness of A356," Materials and Research Express, vol. 7, no. 2, Article ID 026549, 2020.

[40] M. Uludag, R. Çetin, D. Dispinar, and M. Tiryakioglu, "Characterization of the effect of melt treatments on melt quality in Al-7wt \%Si-Mg alloys," Metals, vol. 7, p. 157, 2017.

[41] C. M. Dinnis, A. K. Dahle, J. A. Taylor, and M. O. Otte, "The influence of strontium on porosity formation in Al-Si alloys," Metallurgical and Materials Transactions A, vol. 35, no. 11, pp. 3531-3541, 2004.

[42] M. D. Giovanni, J. M. Warnett, M. A. Williams, and P. Srirangam, "3D imaging and quantification of porosity and intermetallic particles in strontium modified Al-Si alloys," Journal of Alloys and Compounds, vol. 727, pp. 353-361, 2017.

[43] D. Wang, H. Zhang, X. Han, B. Shao, L. Li, and J. Cui, "The analysis of strontium modification on microstructure and mechanical properties of $\mathrm{Al}-25 \% \mathrm{Mg}_{2} \mathrm{Si}$ in situ composite," Journal of Materials Engineering Performance.vol. 26, no. 9, pp. 4415-4423, 2017.
[44] I. N. Ganiev, A. V. Vakhobov, and T. D. Dzhuraev, "Phase diagram of the Al-Si-Sr system," Izvestiya Akademii Nauk SSSR, Metally, vol. 4, pp. 215-219, 1977.

[45] D. Dispinar and J. Campbell, Shape Casting: 5th International Symposium 2014, The Minerals, Metals \& Materials Society, Springer, Berlin, Germany, 2014.

[46] J. Campbell, Complete Casting Handbook, Butterworth-Heinemann, Oxford, UK, 2nd edition, 2015. 